\title{
Bolivianos y bolivianas en Chuquicamata. Caracterización de los flujos migratorios desde el período de la minería artesanal a la era industrial (1881-1942)*
}

\author{
Bolivian men and women Chuquicamata. Characterization of migratory flows from \\ the artisanal mining period to the industrial era (1881-1942)
}

\author{
Damir Galaz-Mandakovic ${ }^{* *}$ \\ Francisco Rivera Amaro ${ }^{* * *}$
}

\section{RESUMEN}

A través del análisis de fuentes primarias, como documentos burocráticos de control migratorio, archivos documentales y hemerográficos, se presenta una cuantificación y una caracterización de la migración boliviana en Chuquicamata entre 1881 y 1942. Presentamos los años de ingreso de hombres y mujeres de origen boliviano, así como sus localidades de origen, oficio, estado civil, edad y alfabetización. Enmarcamos nuestro análisis de acuerdo con cuatro grandes etapas desde un período de explotación artesanal a la explotación industrial bajo capitales estadounidenses. Identificamos una primera etapa de despueble de minas y expropiación a la inversión de bolivianos (1881-1884), una segunda etapa de mediana minería (1885-1911), una tercera etapa de industrialización bajo capitales de la familia Guggenheim (1912-1922) y una cuarta etapa de expansión y explotación por parte de Anaconda Copper (1923-1942). Si bien subestimada por las crónicas coetáneas de cada período, sostenemos que la fuerza de trabajo migrante boliviana fue fundamental para el mantenimiento y desarrollo de la minería cuprífera en Chuquicamata tanto en la etapa de explotación artesanal y mediana como en la primera década de la época industrial.

Palabras claves: Chuquicamata, migración boliviana, The Chile Exploration Company, The Anaconda Copper, minería cuprífera.

\section{ABSTRACT}

The analysis of primary sources, such as bureaucratic documents of migratory control, documentary and newspaper archives, allows a quantification and characterization of the Bolivian migration in Chuquicamata between 1881 and 1942. We present the years of entry of Bolivian men and women, as well as their places of origin, occupation, marital status, age, and literacy. We frame our analysis according to four major stages from a period of artisanal exploitation to industrial exploitation under US

\footnotetext{
* Este artículo es producto del proyecto FONDECYT № 11180932.

** Profesor de Historia y Geografía (Universidad de Tarapacá), Magíster en Ciencias Sociales (Universidad de Antofagasta), Magíster y Doctor en Antropología (Universidad Católica del Norte), Docteur en Histoire (Université Rennes 2 -Université Bretagne Loire, Francia). Filiación: Universidad Católica del Norte, Antofagasta, Chile. ORCID: https://orcid.org/0000-0003-0312-6672. Correo electrónico: damirgalaz@gmail.com.

${ }^{* * *}$ Arqueólogo (Universidad de Chile) Master of Arts en Sciences Historiques: archaeology (University of FribourgNeuchâtel, Switzerland), PhD Anthropology (University of Montreal, Canada). Filiación: Universidad de Montreal, Canadá. https://orcid.org/0000-0003-4938-7392.Correo electrónico: f.riveraamaro@gmail.com.
} 
capital. We identify a first period during the Pacific war (1881-1884), a second pre-industrial period (1885-1911), a third period of industrialization under Guggenheim family capital (1912-1922) and a fourth period of expansion and exploitation by Anaconda Copper (1923-1942). Although underestimated by the contemporaneous chronicles of each period, we argue that the Bolivian migrant labor force was fundamental for the maintenance and development of copper mining in Chuquicamata, both during its artisanal exploitation stage and the first decade of the industrial era.

key words: Chuquicamata, Bolivian migration, The Chile Exploration Company, The Anaconda Copper, copper mining.

Recibido: febrero 2021

Aceptado: mayo 2021

\section{Introducción}

Delfín Huanca Bartolomé, había nacido en Uyuni en 1910. 20 años después, junto a su hermano Crisanto, cruzaron la frontera y llegaron hasta la azufrera de Amincha, famosa por su notable andarivel. Después de algunos meses de trabajo, se dirigieron hacia Aucanquilcha. Fueron cinco años de vida laboral en dichas azufreras fronterizas ${ }^{1}$. No obstante, los datos laborales en la gran mina de Chuquicamata forjaron nuevos imaginarios migrantes. De esa manera, Delfín Huanca se dirigió hacia la cuprífera manejada por capitales estadounidenses, "emporio y usina superiores por su riqueza y las soberbias instalaciones que la hacen figurar como uno de los primeros centros industriales, en su género en América" ${ }^{2}$.

Delfín Huanca ingresó a trabajar en la mina de Chuquicamata en 1936. Fue ahí también donde se casó con Hilara Ustáriz, también de nacionalidad boliviana, quien trabajaba como mesera en un restaurant. Por su parte, Delfín comenzó a desenvolverse en los trabajos mecánicos de la maestranza de Chuquicamata. Lo aprendido en el trabajo, lo estimuló a implementar un pequeño taller en su casa ubicada en el barrio Las Latas, en donde arreglaba todo tipo de artefactos.

Desde aquel centro minero, Delfín Huanca enviaba algunas remesas hacia Uyuni con el objetivo de ayudar a su familia. Lentamente dejó de visitar Uyuni porque sus hijos se enfermaban por el riguroso frío y por la excesiva sequedad. Una vez que Delfín se jubiló en la cuprífera, decidió vivir en Antofagasta, ciudad donde falleció.

El caso de Delfín Huanca nos ilustra la trayectoria de cientos de migrantes bolivianos que vieron en la minería chilena de la posguerra el escenario para migrar, trabajar y transformar sus

\footnotetext{
${ }^{1}$ Carlos Puebla, residente en Antofagasta, yerno de Delfín Huanca, entrevista realizada el 8 de enero de 2014, Antofagasta.

${ }^{2}$ Arce, Isaac. 1997 [1930]. Narraciones Históricas de Antofagasta, Antofagasta, Imprenta Moderna, p. 420.
} 
propias biografías. Del mismo modo, el caso de Delfín nos ayuda a ver cómo la minería del cobre a gran escala, fue el horizonte o el objetivo para muchos migrantes bolivianos.

En este artículo, a través de diversas fuentes primarias, se caracteriza la migración boliviana en el mineral de Chuquicamata, hito minero destacado en el orbe durante gran parte del siglo XX. Hemos considerado la época de explotación a nivel artesanal vivida después de la Guerra del Pacífico y la época de tránsito hacia su explotación industrial bajo capitales estadounidenses. En ese sentido, recurrimos a archivos documentales y hemerográficos interregionales, agregando los antecedentes rescatados en el servicio de Extranjería del Registro Civil e Identificaciones de Antofagasta, acervo documental resguardado por el Archivo Histórico de la Universidad Católica del Norte (en adelante AHUCN). Dichos documentos, nos facilitaron la construcción de una base de datos que contiene 3.794 casos de migrantes bolivianos que ingresaron a Chile entre 1879 y 1946. De ese total, identificamos a 353 bolivianos que migraron directamente hacia Chuquicamata siendo el caso más temprano en 1881 y el más tardío en 1942. De ese modo, podremos caracterizar la propia escena productiva y social del mineral y podremos dar a conocer los datos sobre quiénes, cuándo y cuántos atravesaron la frontera ingresando mayoritariamente por el paso de Ollagüe que, "dista de ocho a nueve horas por ferrocarril (...) por aquel lado no se divisa peligro de que nos invadan los bolivianos, vecinos con quienes estamos hoy en las mejores relaciones" ${ }^{\prime \prime}$.

De esa manera, en el presente trabajo se demuestra que los bolivianos transitaron desde una condición de nativos a una condición de extranjeros en un mismo territorio que fue alterado por una guerra, y que al volver al mismo suelo además de figurar como migrantes internacionales, representan al colectivo que sufrió procesos de discriminación y se transformaron en la mano de obra más precarizada y subalterna por efecto de la nueva semántica sociológica de la minería. En ese sentido, la migración boliviana se densificó en la primera etapa de industrialización, al menos en la primera década (1915-1925), siendo crucial su mano de obra para el inicial proceso de industrialización en manos de los Guggenheim, una etapa caracterizada por la precariedad e inseguridad laboral. No obstante, el declive cuantitativo de la migración boliviana en Chuquicamata está correlacionado a varios factores, entre ellos, al traspaso de la propiedad de la mina en el primer lustro de la década de 1920, también se articula con la densificación de la tensión entre chilenos y bolivianos, además de los procesos de reivindicación laboral y mejoramiento de condiciones de trabajo, gracias a la legislación de 1924, que implicó la creación de una institucionalidad de regulación laboral, lo cual generó que el reconocimiento y protección de derechos laborales fuera ascendiendo, proceso que es coronado por la sindicalización desde 1931. Simultáneamente se evidencian

3 Gutiérrez, Eulogio y Marcial Figueroa. 1920. Chuquicamata: Su grandeza y sus dolores, Santiago, Imprenta Cervantes, p. 184. 
discursos xenofóbicos. De igual modo, la nueva administración de la mina fue mejorando las condiciones del habitar en el company town y los procesos de regulación en la frontera se fueron endureciendo en la misma década por parte del Estado. En síntesis, es posible plantear que la migración boliviana sustentó la expansión inicial de la industrialización de Chuquicamata, siendo voluminosa en una época de escasa protección legal, lo que retrata el carácter subsidiario de esta movilidad laboral.

\section{Bolivianos en Atacama}

El primer censo chileno aplicado en el desierto de la posguerra fue en 1885, indicando que el Departamento de Antofagasta poseía 16.549 habitantes. Por su parte, el Departamento de Tocopilla, contaba con 4.664. Así, en la Provincia de Antofagasta había 5.291 extranjeros (31.9\%) y 1.228 en Tocopilla $(26.3 \%)^{4}$. En 1895, la misma provincia poseía 44.085 habitantes, de los cuales, 2.496 eran bolivianos (1.228, hombres y 1.268 mujeres) ${ }^{5}$. Ya en 1907, los bolivianos eran 5.296, distribuidos en el área rural como en el espacio urbano. Reveladora cifra en una ciudad de 31.466 habitantes: los bolivianos encarnaban el 16,8\% de la población ${ }^{6}$.

El censo de 1920, indica que el Departamento de Antofagasta contenía una población de 101.604 habitantes, por su parte, la ciudad homónima sumaba 51.531. De esa manera, se cuentan 6.177 bolivianos (3.559, hombres; 2.618 , mujeres). Los bolivianos constituían el 11,9\% de la población antofagastina ${ }^{7}$.

En el censo de 1930 la población boliviana se redujo en comparación a las contabilizaciones realizadas en 1907 y 1920: en 1930 se registran 4.715 bolivianos en la Provincia de Antofagasta (2.718 hombres; 1.997 mujeres). Lo que equivale a 1.462 bolivianos menos que el censo de 1920, a saber, que en Chile se registraba un total de 10.366 bolivianos $^{8}$. De esa manera, podemos decir que en la Antofagasta de 1930 residía el 45,4\% de la población total de bolivianos en Chile, en una ciudad que contabilizaba 53.591 habitantes. Este descenso está inscrito en el desmantelamiento de las salitreras del sistema Shanks, desde 1919, y a la posterior crisis iniciada en 1929.

\footnotetext{
${ }^{4}$ Oficina Central de Estadística en Santiago.1889. Sesto Censo Jeneral de la población de Chile levantado el 26 de noviembre de 1885 y compilado por la Oficina Central de Estadística en Santiago. Valparaíso, Imprenta de La Patria. ${ }^{5}$ Oficina Central de Estadística. 1900. Sétimo Censo jeneral de la población de Chile levantado el 28 de noviembre de 1895, Valparaíso, Imprenta del Universo de Guillermo Helfman.

${ }^{6}$ Comisión Central del Censo. 1908. Censo de la República de Chile levantado el 28 de noviembre de 1907, Santiago, Imprenta y Litografía Universo.

7 Dirección General de Estadísticas. 1925. IX Censo de Población de la República de Chile levantado el 15 de diciembre de 1920, Santiago de Chile, Sociedad Imprenta y Litografía Universo.

8 Dirección General de Estadísticas. 1931. Resultados del X Censo de Población efectuado el 27 de noviembre de 1930 y estadísticas comparativas con censos anteriores, Santiago de Chile, Dirección General de Estadísticas, Imprenta Universo.
} 
Todas estas cifras muestran la presencia importante de migrantes bolivianos que participaban en la sociedad minera de la zona incorporada por causa de una guerra. La memoria del territorio, la existencia de redes familiares y sociales, además de la inauguración de proyectos extractivos, constituyeron un espacio transfronterizo que articuló importantes trasiegos.

Por otra parte, en la revisión de los 3.794 casos de migrantes bolivianos en Chile registrados en el Servicio de Extranjería del Registro Civil e Identificaciones de Antofagasta, podemos ver que dicha migración se distribuyó en 87 poblados del desierto antofagastino, poblados que pueden ser diferenciados en 7 tipos de áreas en cuanto a las actividades productivas que desarrollaban, las cuales abarcan desde la costa hasta la precordillera, evidenciándose centros microurbanos que enlazaron redes sociales, materialidades e insumos, aquellos son: 1) Ciudades, 2) Oficinas salitreras, 3) Minas de plata, 4) Minas de cobre, 5) Pueblos precordilleranos, 6) Azufreras y borateras y 7) Estaciones ferroviarias. Sobre los 10 primeros poblados indicados como destino, podemos ver que la ciudad de Antofagasta concentra la mayoría (32,4\%), Chuquicamata aparece como segundo destino $(9,3 \%)$ por sobre la ciudad de Calama (

gráfico 1).

\section{Gráfico 1}

Primeras 10 comunidades chilenas indicadas como destino por parte de los migrantes bolivianos entre 1879 y 1946

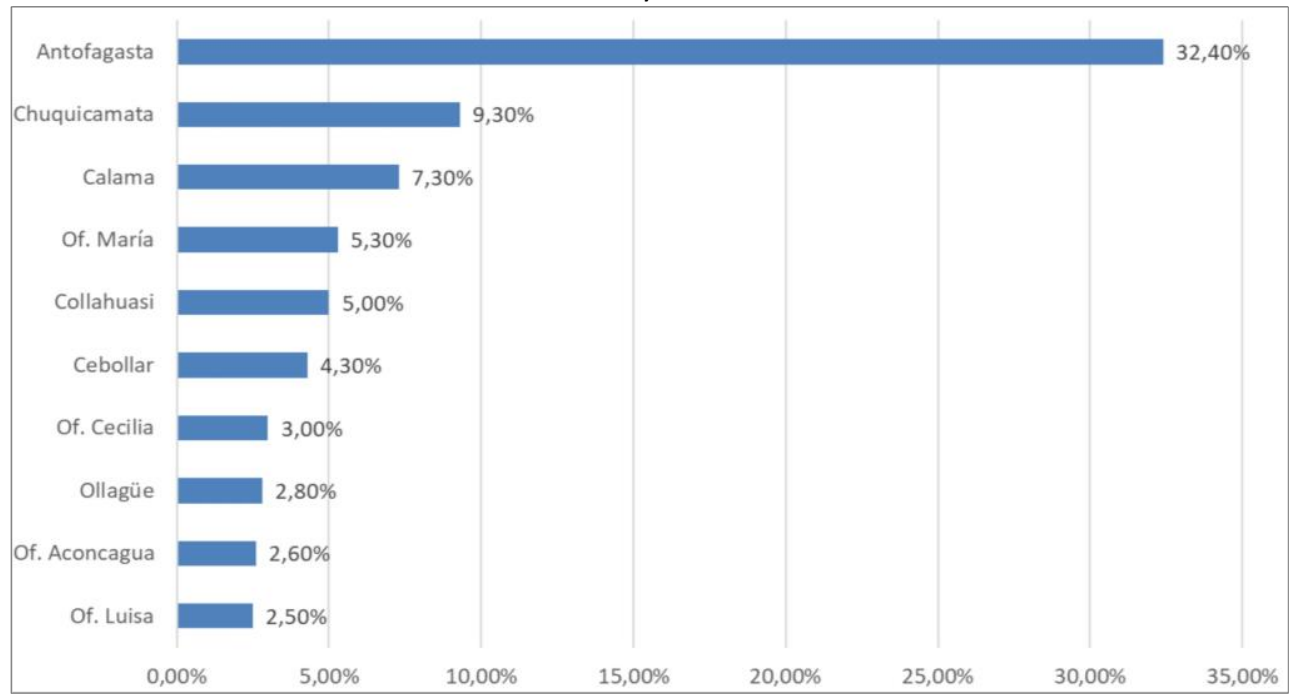

Fuente: Archivo Histórico Universidad Católica del Norte, Fondo Archivo de Extranjería del Registro Civil e Identificación de Antofagasta, migración boliviana 1879-1946. Elaboración propia.

Evidentemente, fueron muchos más los bolivianos que habitaron en Chuquicamata. Hemos sabido de nombres que no aparecen en los registros estatales chilenos. Muchos bolivianos al 
ingresar por Ollagüe indicaron otros destinos, pero una vez que estaban en Chile desarrollaron múltiples movilidades abarcando varios centros mineros, tal como fue el caso del uyunense Delfín Huanca Bartolomé. Del mismo modo, debemos mencionar la propia porosidad de la frontera donde no siempre los ingresos fueron registrados por efecto de existir diversas rutas, huellas, senderos, pasos y heteróclitos caminos agenciados por habitantes que devinieron en fronterizos por causa de la Guerra del Pacífico. A través de esas porosidades, siguiendo a Lefebvre, podemos decir que "los senderos son como poros que se agrandan" ${ }^{9}$, en un espacio que se pretende "abierto a las razones autorizadas o establecidas" ${ }^{10}$.

Gráfico 2

Número de ingresos de migrantes bolivianos hacia Chuquicamata entre 1881 y 1942

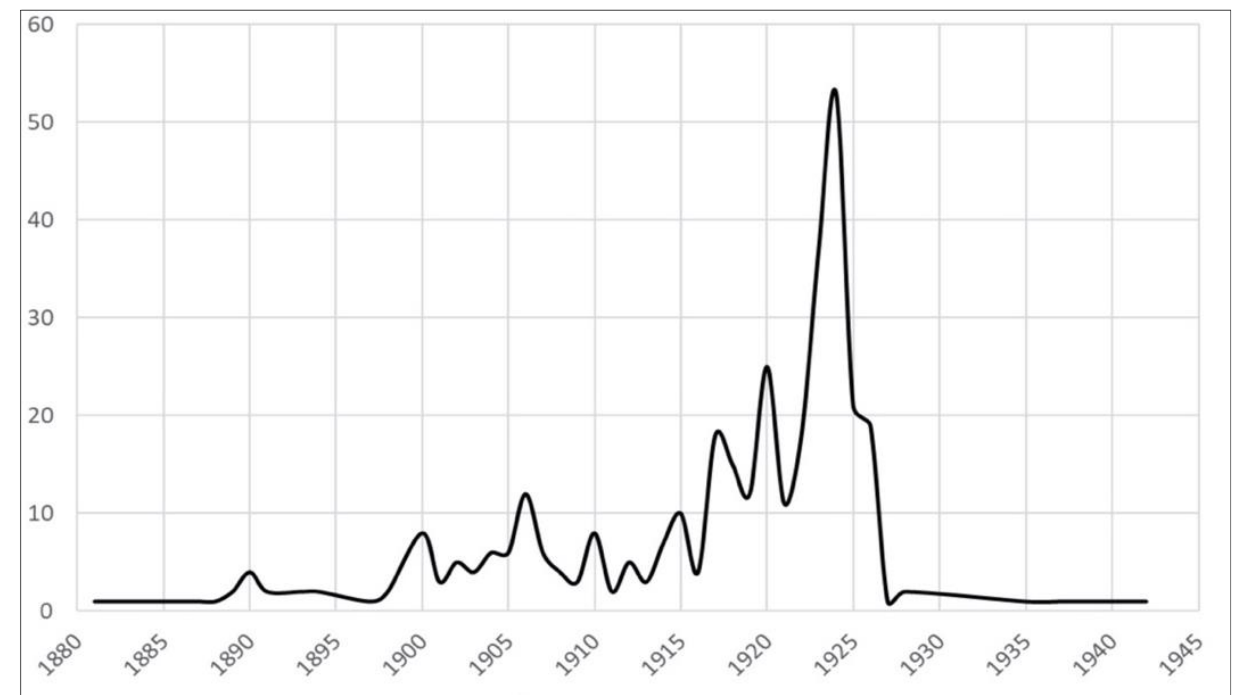

Fuente: Archivo Histórico Universidad Católica del Norte, Fondo Archivo de Extranjería del Registro Civil e Identificación de Antofagasta, migración boliviana 1879-1946. Elaboración propia.

En el análisis de los datos del archivo, podemos ver que el total de ingresos de hombres y mujeres de origen boliviano al mineral de Chuquicamata muestra una tendencia ascendente hasta el año 1915, con un fuerte aumento hacia los años 1923 y 1924 (Gráfico 2). Luego, en 1925 los ingresos decaen abruptamente. Estos datos coinciden con el período posterior a la venta de la mina por parte de los Guggenheim a Anaconda Copper en 1923, modificando no solamente los flujos de capital, sino que también el movimiento migratorio de los trabajadores extranjeros, en este caso desde Bolivia.

\footnotetext{
${ }^{9}$ Lefebvre, Henri. 2013. La producción del espacio, Madrid, Capitán Swing Libros, p. 238.

${ }^{10}$ Ibíd., p. 237.
} 
Para caracterizar y analizar la migración boliviana en Chuquicamata, hemos realizado la siguiente periodificación concerniente a los patrones de administración, gestión y propiedad de la mina de Chuquicamata, como así también a los modos de habitar el mineral (Tabla 1).

Tabla 1

Periodificación de los modos de producción, los modos de habitabilidad y la propiedad del mineral de Chuquicamata desde el siglo XIX hasta la primera mitad del siglo XX

\begin{tabular}{|c|c|c|c|c|}
\hline Período & Denominación & Capitales & Descripción & Localidades y campamentos \\
\hline 1881-1884 & $\begin{array}{l}\text { Etapa de } \\
\text { despueble y } \\
\text { expropiación } \\
\text { de la inversión } \\
\text { boliviana }\end{array}$ & $\begin{array}{l}\text { Empresas y } \\
\text { agencias } \\
\text { particulares de } \\
\text { origen boliviano. }\end{array}$ & $\begin{array}{l}\text { Concerniente al } \\
\text { desarrollo de la Guerra } \\
\text { del Pacífico, implicando } \\
\text { el cambio de } \\
\text { nacionalidad del } \\
\text { territorio, lo que } \\
\text { significó el despueble } \\
\text { de minas y procesos de } \\
\text { expropiación. }\end{array}$ & $\begin{array}{l}\text { Caseríos dispersos, tolderías } \\
\text { en las afueras de los } \\
\text { socavones. }\end{array}$ \\
\hline $1885-1911$ & $\begin{array}{l}\text { Etapa de } \\
\text { Mediana } \\
\text { minería }\end{array}$ & $\begin{array}{l}\text { Empresas y } \\
\text { agencias } \\
\text { personales de } \\
\text { origen chileno y } \\
\text { extranjero. }\end{array}$ & $\begin{array}{l}\text { Diversas explotaciones } \\
\text { a pequeña y mediana } \\
\text { escala a } \\
\text { través de piques y } \\
\text { socavones con } \\
\text { métodos y tecnologías } \\
\text { artesanales. }\end{array}$ & $\begin{array}{l}\text { Placilla } \\
\text { Banco Drummond } \\
\text { Punta de Rieles } \\
\text { Caseríos dispersos }\end{array}$ \\
\hline 1912-1922 & $\begin{array}{l}\text { Etapa } \\
\text { Guggenheim }\end{array}$ & $\begin{array}{l}\text { Empresa } \\
\text { principal: The } \\
\text { Chile Exploration } \\
\text { Company, de } \\
\text { origen } \\
\text { estadounidense. }\end{array}$ & $\begin{array}{l}\text { Etapa de } \\
\text { industrialización a } \\
\text { través del sistema open } \\
\text { pit. }\end{array}$ & $\begin{array}{l}\text { Campamento El Cobre } \\
\text { (dentro de la mina). } \\
\text { Construcción del } \\
\text { Campamento Nuevo. } \\
\text { Implementación del } \\
\text { Campamento de Nativos. } \\
\text { Campamento Americano. }\end{array}$ \\
\hline $1923-$ & $\begin{array}{l}\text { Etapa } \\
\text { Anaconda } \\
\text { Copper }\end{array}$ & $\begin{array}{l}\text { Empresa } \\
\text { principal: The } \\
\text { Anaconda } \\
\text { Copper Mining } \\
\text { Co., teniendo } \\
\text { como subsidiaria } \\
\text { a The Chile } \\
\text { Exploration } \\
\text { Company }\end{array}$ & $\begin{array}{l}\text { Expansión de la } \\
\text { explotación a través } \\
\text { del sistema open pit y } \\
\text { la consolidación del } \\
\text { sistema de electrolisis } \\
\text { para el refinamiento } \\
\text { del cobre. }\end{array}$ & $\begin{array}{l}\text { Consolidación del Company } \\
\text { Town. } \\
\text { Ampliación de la población } \\
\text { Los Adobes (1917-1942). } \\
\text { Construcción de los Tipos C } \\
\text { (1920-1926). } \\
\text { Campamento Los } 600 \text { (1920- } \\
\text { 1926). } \\
\text { Implementación de } \\
\text { habitaciones Los Buques } \\
\text { (1923-1945). } \\
\text { Implementación de población } \\
\text { Los Hundidos (1921-1943). } \\
\text { Implementación de población } \\
\text { Los 2000 (1926-1945). }\end{array}$ \\
\hline
\end{tabular}

Esquema: elaboración propia. 
El decenio 1920-1929 concentra el 53\% del total de ingresos, con un número importante de inmigrantes en la década anterior 1910-1919 con el 23,8\% del total registrado. Si observamos el movimiento migratorio por períodos de administración de Chuquicamata y no por decenios, vemos que el período entre 1912 y 1922 concentra el 36,3\% del total de ingresos, y el período posterior entre 1923 y 1942, el $38,8 \%$. No obstante, el descenso de la migración pasado el año 1924 es evidente y sustancial.

Si comparamos los flujos migratorios de bolivianos con la productividad de la mina, podemos ver que existió una clara correlación al menos hasta 1924, momento en que se cumplían los primeros nueves años de industrialización. Desde el año siguiente, podemos ver que se inicia el descenso del flujo, cayendo abruptamente hacia 1927. Naturalmente, con la crisis mundial iniciada en 1929, la producción tuvo un descenso que se mantuvo hasta 1932. Al año siguiente, la producción de cobre refinado tuvo un ascenso pero que no se condice con los flujos migratorios bolivianos (Gráfico 3).

\section{Gráfico 3}

Indicador histórico de la producción de cobre refinado en Chuquicamata (etapa industrial) desde 1914 hasta 1942, cruzada con el indicador de los flujos bolivianos hacia el mineral para el mismo periodo

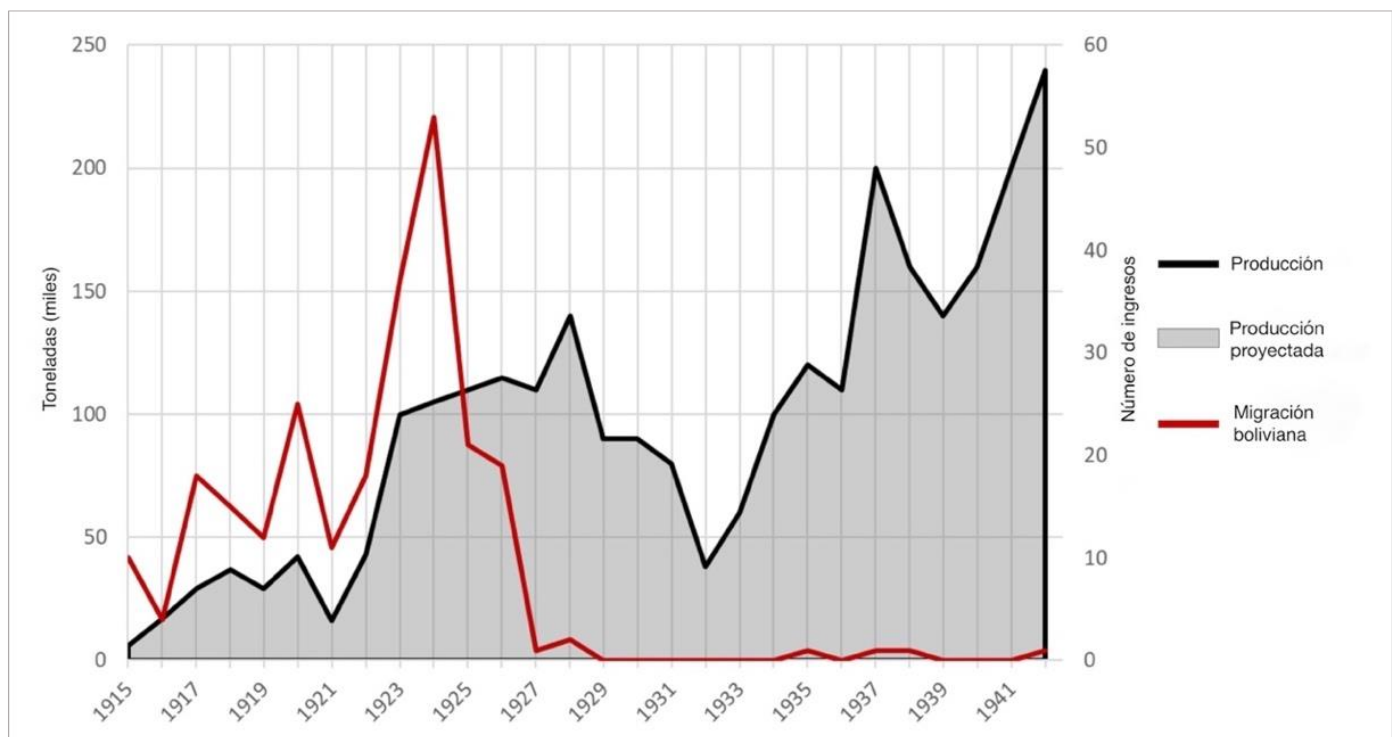

Fuente para ciclo productivo: The Anaconda Company (1970). Fuente para migración: Archivo Histórico Universidad Católica del Norte, Fondo Archivo de Extranjería del Registro Civil e Identificación de Antofagasta, migración boliviana 1879-1946. Esquema: elaboración propia.

\section{La Chuquicamata de la mediana minería}

Durante el siglo XIX, los filones del yacimiento de Chuquicamata fueron trabajados por mineros bolivianos a través de la excavación realizada por cuñas, adicionando los combos, barretas, 
chuzos y palas ${ }^{11}$, "pequeños industriales que careciendo de pericia y no disponiendo de recursos [...] lo hacían rústicamente y con la añadidura de desesperados esfuerzos"12. Así, el mineral fue trabajado por algunas empresas que implementaron establecimientos de beneficio, tales como el de Chinchorante, Yalquincha y en la zona de Chorrillos en Calama ${ }^{13}$.

La Guerra del Pacífico y el cambio de nacionalidad del territorio, promovió la caducidad de los títulos ${ }^{14}$ : "Ios títulos bolivianos de ninguna de las minas en el distrito de Atacama subsistieron después de la guerra. Durante la guerra todos los habitantes abandonaron el campamento y perdieron por tanto sus pertenencias" ${ }^{15}$.

Después de la guerra, devino un proceso de apogeo de los trabajos en la zona de Chuquicamata, siendo uno de los precursores Luis Camus ${ }^{16}$ quien trabajó sectores de llamperas o de metales "menudos"17 o también conocidos como filones superficiales, generando una verdadera gravitación de diversos buscones, pirquineros y cateadores. De igual modo, los trabajos en la mina Zaragoza, de Antonio Toro, despertó un gran interés. En 1882 había 10 piques mineros ${ }^{18}$ de importancia ${ }^{19}$.

${ }^{11}$ Collao, Juan. 2001. Historia de Tocopilla (obra póstuma), Tocopilla, Ed. Corporación Juan Collao Cerda, p. 189.

12 Figueroa, Marcial. 1928. Chuquicamata: la tumba del chileno, Antofagasta, Imprenta Castellana, p. 31.

${ }_{13}$ Martínez, G. 1993. Orígenes y desarrollo de Chuquicamata bajo la Chile Exploration Company, Santiago, Ediciones Revista Universitaria, p. 8.

${ }^{14}$ Según los prontuarios del Archivo de Extranjería del Registro Civil e Identificación de Antofagasta, migración boliviana 1879-1946, en la zona agregada a Chile, se registran entre los años 1879 y 1885, 144 bolivianos, distribuidos en diversos poblados de la costa, algunas Oficinas salitreras y pueblos precordilleranos.

${ }_{15}$ Revista Ingeniería Internacional. 1922. "El mineral de Chuquicamata”, Tomo 7, № 5, Nueva York, p. 297.

${ }^{16}$ Álvarez, Alejandro. 1999. Resumen de la historia de Calama, Calama, Ediciones Odisea, p. 51.

${ }_{17}$ Revista Ingeniería Internacional. 1922. “El mineral de Chuquicamata”, Tomo 7, № 5, Nueva York, p. 295.

18 González, José Antonio. 2010. "La industria minera de Antofagasta y la inmigración boliviana durante el ciclo salitrero. Notas para su estudio", en Si Somos americanos: Revista de Estudios transfronterizos, Vol. X, № 2, p. 102.

${ }^{19}$ En el año 1898 visitó Chuquicamata el escocés Norman Walker, quien pudo apreciar el valor del mineral. Por tales razones, compró varias zonas de llamperas y procedió a lixiviar algunos metales vendiendo a 33 libras esterlinas la tonelada (Revista Ingeniería Internacional. 1922. "El mineral de Chuquicamata", Tomo 7, № 5, Nueva York, p. 296). Desde entonces, se anotaron más de 300 pertenencias mineras, abriéndose una época de intenso extractivismo a escala artesanal (Alvear, Jorge. 1975. Chile, nuestro cobre. Chuquicamata, El Salvador, Potrerillos, El Teniente, ENAMI, Mantos Blancos y Andina, Santiago, Editorial Lastra, p. 59), transformando el lugar en una "colmena humana" (Collao, Juan. 2001. Historia de Tocopilla (obra póstuma), Tocopilla, Ed. Corporación Juan Collao Cerda, p. 189), donde palliris, chancadores, barreteros, apires, muestreros, empresarios y aventureros comenzaron a multiplicarse. Los nombres que comenzaron a destacar fueron Abel Alcota, Andrés Ahumada, Baldomero Toro, Carlos de la Fuente, Cesáreo Aguirre, Manuel Álvarez, Eduardo Delano, Julio Pinkas, Feliciano Ibaceta, H. M. Drummond, José Antonio Villalobos, Juan Santelices, Luis Chabrat, Manuel Rojas Alcayaga, Manuel y José Toyos, Miguel Zuleta y la Casa Weber y Steinle de Hamburgo, esta última creadora de la Sociedad Exploradora de Chuquicamata, empresa sin mucho éxito. Por su parte, la empresa que formó Enrique Villegas Encalada y Walter Andrews, la Compañía Poderosa en 1899, fue un poco más exitosa. Otras sociedades pequeñas fueron la Compañía de Cobre de Antofagasta, formada en 1900 y a la casa inglesa de Duncan Fox; la Compañía Minera Teodora, en 1901; la Sociedad Beneficiadora de Chuquicamata, en 1902; la Compañía de Minas y Fundición de Calama de Carlos Gregorio Avalos, formada en 1903 (Arce, Isaac. 1997 [1930]. Narraciones Históricas de Antofagasta, Antofagasta, Imprenta Moderna, p. 420; Alvear, Jorge. 1975. Chile, nuestro cobre. Chuquicamata, El Salvador, Potrerillos, El Teniente, ENAMI, Mantos Blancos y Andina, Santiago, Editorial Lastra, p. 60). 
"El estado jeneral del mineral es bueno, la producción de las minas ya formadas aumenta, $\mathrm{i}$ hai otra que, después de injentes gastos i grandes sacrificios de parte de sus dueños, como la Tres Marías, empezaran una esplotación regular" ${ }^{20}$. Así comentaba sobre la escena de la minera chuquicamatina el periódico bisemanal El Comercio el 19 de abril de 1902, agregando que los empresarios Drummond y Pigott estaban agenciando sustantivas compras de minerales con una ley del $6 \%$, porcentaje común en dicha zona extractiva. Por efecto de dichas compras, se evidenciaba un importante aumento de la población porque gracias a esas compras de Drummond y Pigott, "muchas minas i llamperas que antes no se esplotaban, empezaran a esplotarse ahora. En una palabra, puede decirse que Chuquicamata empieza a levantarse de la postración en que yacía" ${ }^{21}$, consignaba El Comercio ${ }^{22}$.

Adicionalmente, las noticias sobre aquel "emporio de cobre" ${ }^{23}$, también revelaban que la moneda corriente era el sistema de fichas "un sistema anticonstitucional" ${ }^{24}$, sistema de "indiscutibles ventajas para los dueños de las minas", generando protestas y pleitos al momento de reducir las fichas a moneda legal, acciones que generaba una pérdida del $20 \%$ al $30 \%$ en su valor nominal ${ }^{25}$. Es por ello que aquel sistema era acusado como un régimen violatorio y contrario a los derechos y libertades del comercio y del individuo. En 1913 aún existían fichas, al menos así lo denuncia Luis Emilio Recabarren: "La moneda corriente en el mineral son vales que son cambiados por dinero con el $20 \%$ de descuento" ${ }^{26}$, agregando que, en el arreglo de cuentas, "ocurre muy a menudo que los patrones trampean el verdadero valor del trabajo" 27.

Por otra parte, las seguidas menciones a riñas y borracheras era una constante en El Comercio, publicación que imploraba por una biblioteca popular para así evitar las borracheras y estimular "la afición a la economía i el ahorro, menos robos i menos muertes trájicas" ${ }^{28}$. Del mismo modo, la urgencia de mejorar la policía era otra moción periodística para procurar por

\footnotetext{
${ }^{20}$ El Comercio (Calama) [en adelante, ECC], 19 de abril de 1901.

${ }^{21}$ ECC, 19 de abril de 1901. que, por desconocimiento, caían en importantes profundidades.

${ }^{23} \mathrm{ECC}, 24$ de abril de 1901.

${ }^{24}$ ECC, 24 de abril de 1901.

${ }^{25}$ ECC, 24 de abril de 1901.

${ }^{26}$ El Despertar de los Trabajadores (Iquique) [en adelante, EDT], 11 de marzo 1913.

27 EDT, 11 de marzo 1913.

${ }^{28}$ ECC, 24 de abril de 1901.
}

22 En ese tenor de renacimiento, se imploraba a las autoridades departamentales a que favorecieran el desarrollo de las vías de comunicación, indicándose que era urgente el retiro de algunos desmontes para facilitar los flujos en las diversas huellas que estaban obstruidas, especialmente las que conectaban con las minas La Despreciada, La Evanjélica y Dolores. Igualmente, se demandaba la acción de los agentes del Estado en cuanto al control que debían ejercer sobre los dueños de las minas a cerrar los piques y diversos pozos que generaban graves accidentes en la importante cantidad de personas que circulaban de noche por dichos yacimientos, muchos de ellos recién allegados 
el "cumplimiento estricto de la lei de alcoholes"29. Según la publicación calameña, "la policía de Chuquicamata da vergüenza (...) su jefe inmediato tiene por domicilio un burdel de una tal Sinforosa" ${ }^{30}$. También comentaba que la corrupción policial había generado algunos alzamientos del "populacho ebrio" generando incendio y destrucción. Ciertamente, la escena del mineral era conflictiva, surgiendo hechos macabros como violaciones grupales contra mujeres ${ }^{31}$.

Punta de Rieles ${ }^{32}$, considerada como una "fonda permanente" ${ }^{33}$, junto con Placilla, fueron también los antecedentes de urbanización de Chuquicamata, era allí donde había alojamientos, cantinas y posadas. En dichos caseríos: "alternaban ingleses, franceses, españoles, chilenos, bolivianos, yugoslavos y alemanes (...) sin olvidarnos que los chilenos altiplánicos y bolivianos hablaban en aymara" ${ }^{34}$.

La escena minera remitió a la precariedad de los trabajos, los cuales eran físicamente exigentes, eran muchos los cuerpos sacrificiales que penetraban en los piques para ir tras la riqueza mineral con técnicas, tecnologías y mecánicas que conjugaban saberes artesanales y autóctonos, en donde finalmente, las intuiciones de los cateos eran el centro organizador de la búsqueda en el universo cuprífero. Ante la gran cantidad de accidentes, Luis Emilio Recabarren mencionó: “...como en todas partes, se carece de elementos de ambulancia y de salud para atender oportunamente a las víctimas de accidentes o enfermedades" 35 .

En el decir de Samuel Valdés, el operario de superficie en Chuquicamata, "o sea peón de cancha, gana dos pesos día, el barretero cobra doce pesos, siendo de su cuenta la extracción de la saca" ${ }^{36}$. No obstante, los trabajos y los modos de extracción eran precarios y físicamente exigentes. Esa misma precariedad fue descrita por el periódico El Comercio de Calama en 1898: "el mineral de cobre de Chuquicamata (...) ha sido objeto de una constante esplotación debilitada o robustecida con las bajas o alzas en el precio del cobre. Chuquicamata solo ha sido

\footnotetext{
${ }^{29}$ ECC, 24 de abril de 1901.

${ }^{30} \mathrm{ECC}, 24$ de abril de 1901.

${ }^{31}$ El periódico bisemanal El Comercio publicó el 3 de octubre de 1903 que una mujer había sido asaltada por "pillos conocidos", mujer que, una vez asaltada le quitaron sus ropas, "después de haberla despojado, los pillos entregaron a su víctima a la voracidad de varios individuos que esperaban el momento oportuno para saciar en la pobre mujer brutales instintos". Algunos testigos compadecidos con la víctima trataron de defenderla, "pero eran agredidos a calichazos por los que esperaban su turno".

${ }^{32}$ La toponimia de Punta de Rieles tiene que ver con que allí desembocaban todos los ramales que terminaban en punta, simulando una flecha. Éste se ubicaba al suroeste del campamento. El ferrocarril se instaló debido a los peligros de transportar el metal en mula. El último destino de los convoyes era un conjunto de garitos y "casas de remoliendas", desde la estación hacia el norte estaban las casas. En Pumarino Soto, Héctor. 1978. El Loa, ayer y hoy, Santiago, Ediciones Universitarias, pp. 22-23.

33 Álvarez, Alejandro. 1999. Resumen de la historia de Calama, p. 55.

34 Tapia, Gustavo. 2001. Chuquicamata, p. 36.

35 EDT, 11 de marzo de 1913.

${ }^{36}$ Valdés, Samuel y Latrille, Francisco. 1886. Informe sobre el estudio minero i agrícola de la rejión comprendida entre el paralelo 23 i la laguna de Ascotán presentado al Ministerio del Interior, Santiago, Imprenta Nacional, pp. 67.
} 
revuelta superficialmente, no hai minas profundas, la mina Zaragoza, perteneciente a don Cesáreo Aguirre, sólo alcanzó a ciento i tantos metros de profundidad cuando fue paralizada por la baja habida por el precio del cobre años atrás" ${ }^{37}$. La citada publicación agrega que la mina en la que se trabaja a mayor hondura era la mina San Luis: "Hemos visto minerales de $40 \%$ más o menos y muestras de $60 \%$ de cobre puro" ${ }^{38}$. Proseguía en importancia la mina Poderosa y la mina Rosario del Llano. En un segundo nivel destacaban la mina Zaragoza, Emilia, Teodora y la mina San Rafael.

Figuras 1 a 4

Diversas instalaciones y tecnologías en las minas de Chuquicamata en 1899
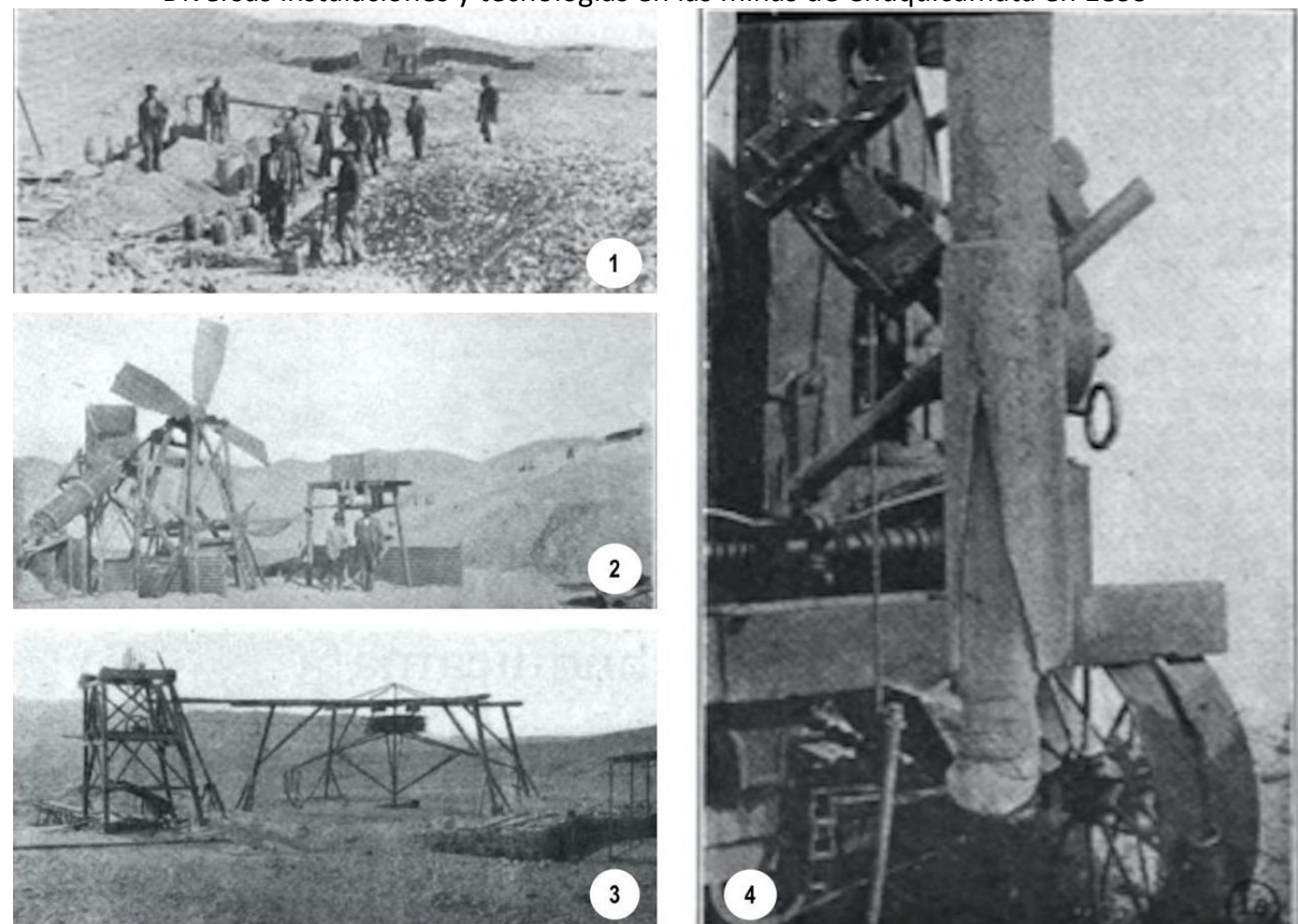

1. Obreros que apartan y separan los minerales a mano. 2. Cribas con molino de viento. 3. Malacate antiguo con tracción animal, también llamado "a sangre". 4. Barrena de sonda cementada con cobre. Fuente: Revista Ingeniería Internacional. 1922. "El mineral de Chuquicamata", Nueva York 1922, Tomo 7, № 5. Esquema: Elaboración propia.

Así, en el primer lustro del siglo XX, Chuquicamata ya sostenía un prestigio de ser sin duda el principal centro de producción de minerales de cobre de Chile, produciendo al mes "dos mil

\footnotetext{
${ }^{37}$ ECC, 7 de abril de 1898.

${ }^{38} \mathrm{ECC}, 7$ de abril de 1898.
} 
toneladas de lei de 17 por ciento, lo que importa al año más de cuatro mil toneladas de cobre, o sea la sesta parte de la producción de Chile"${ }^{39}$.

En todo este contexto, los obreros bolivianos "los varios hijos del Tunari o elevado Illimani" ${ }^{40}$, eran despreciados por los diarios. En enero de 1902, se publicó una columna titulada como "La indiada", donde se expresaba una queja frente a la participación de bolivianos en diversos puestos públicos quienes, según el diario, en Antofagasta y Calama "alientan a la indiada [...] a resistir la ciudadanía chilena" ${ }^{41}$. A lo que acometía con acusaciones fuertes, señalando que "dicha indiada vale bien poco: es la sustancia de los tres vicios predominantes en los países limítrofes [...] siendo por consiguiente rateros, borrachos i flojos. Con tales cualidades no sirven [...] ni para ciudadanos". Las imputaciones racistas y xenófobas contra los bolivianos se sintetizan del siguiente modo: "estas razas decrépitas son un estorbo a la civilización, i por ellas, como el bien de la jeneralidad, debiera el Congreso apresurar a dictar la lei de instrucción obligatoria" 42 .

En 1904, la misma publicación de Calama polemizaba con El Industrial de Antofagasta, en cuanto a que este último había publicado una nota sobre las graves rencillas y riñas entre trabajadores chilenos y bolivianos en el mineral de Chuquicamata, a lo que El Comercio indicaba: "tal vez ha sido sueño del que contó el cuento al decano de la prensa de la provincia, pues que aquí no ha se visto ninguna, no menos que ha haya habido combate entre chilenos $\mathrm{i}$ bolivianos, así que la sangre corrida solo ha estado en la imajinación del articulista". De igual modo, el periódico calameño desmentía la noticia que señaló que existían enganches de "jente boliviana i que estos trabajan por la comida", a lo que reafirmaba que los bolivianos que había "se ganan sus cincos pesos diarios, i el contratista sabiendo que está en un país libre, no le pregunta a ningún trabajador que se presenta a qué nacionalidad pertenece para darle trabajo". En las consecutivas líneas, El Comercio acusaba a El Industrial de cierta selectividad en la odiosidad hacia el extranjero en el desierto minero, sugiriendo que mejor sería que El Industrial reclamara por "todos los estranjeros que hai en Antofagasta" ${ }^{43}$.

\section{Etapa industrial bajo control estadounidense}

El interés de los hermanos Guggenheim por la zona de Chuquicamata estuvo estimulado por diversos factores: el primero de ellos, por la información geológica certera sobre la zona y por la potencia extractiva que poseía. Además, el repunte del precio del cobre a contar del año 1896 fue un significativo estímulo para la configuración de numerosas sociedades mineras que

\footnotetext{
${ }^{39}$ ECC, 9 de julio de 1904.

40 ECC, 8 de agosto de 1901.

41 ECC, 28 de enero de 1902.

42 ECC, 28 de enero de 1902.

43 ECC, 12 de noviembre de 1904.
} 
luchaban por obtener diversos pedimentos mineros. Este repunte del precio del cobre vino a generar una ruptura con la tendencia a la baja que se había iniciado con la crisis económica en Chile, especialmente en el año 1873.

Otro factor de interés lo constituyó la ampliación del ferrocarril que venía desde Antofagasta, el cual en 1886 llegó hasta Calama. Era la escena de la ampliación mecánica inaugurada por la Compañía Huanchaca de Bolivia que finalmente articuló Antofagasta con Uyuni-y luego Oruro- para exteriorizar la producción de la mina Pulacayo. Cabe indicar que los hermanos Guggenheim habían arrendado a la Compañía Minera Huanchaca, la Fundición de Playa Blanca, ubicada a cuatro kilómetros al sur de Antofagasta. Esta situación les posibilitó el conocimiento del rendimiento o capacidades de los numerosos piques de la zona chuquicamatina ${ }^{44}$. Otro proceso novedoso lo constituyó el nuevo Código de Minería de 1888, el cual modificó el régimen de amparo de la propiedad minera, significando la mantención de la propiedad con el pago de una patente anual ${ }^{45}$. A su vez, el Código estaba sustentado en la liberalidad del desarrollo de la minería ${ }^{46}$, el cual produjo "la desaparición de uno de los más tradicionales principios del régimen minero: el trabajo efectivo, como forma de justificar el otorgamiento de la concesión minera" ${ }^{47}$.

El acercamiento de los Guggenheim tiene que ver también con la configuración de dos importantes sociedades: la Compañía de Cobres de Antofagasta, en 1899, siendo los socios Norman Walker, la conocida sociedad de Duncan Fox y la Sociedad Explotadora de Chuquicamata que se constituyó en 1903. Ésta última sociedad suscribió un contrato de arriendo de pertenencias mineras con Albert Burrage ${ }^{48}$, quien fue ingeniero en Boston, banquero, amigo y consejero de los hermanos estadounidenses ${ }^{49}$.

44 Galaz-Mandakovic, Damir. 2017. Inclusions, transformations et asymétries du capitalisme minier sur la cote d'Atacama: les dérives de la production thermoélectrique a Tocopilla (Chili) 1914-2015, Tesis para optar al grado de doctor en Antropología en Instituto de Arqueología y Antropología, Universidad Católica del Norte, San Pedro de Atacama, y al grado de Doctor en Historia en Université Rennes 2, Rennes, Francia.

${ }^{45}$ El primer Código de Minería de Chile entró en vigor el 1 de marzo de 1875.

${ }^{46}$ Cabe señalar que el procedimiento general de constitución de pertenencias establecido en el Código Minero de 1888 se iniciaba con un escrito llamado manifestación o pedimento, que informaba el hallazgo minero, el cual debía registrarse ante un notario; luego se exigía la ratificación de esta petición que igualmente se inscribía y que constituía un título provisorio, para luego pedir el alinderamiento provisorio y, finalmente, la mensura de la concesión, cuya acta se inscribía y constituía el título minero definitivo. Orellana, Luis. 2004. "La lucha de los mineros contra las leyes: Chuquicamata (1900-1915)", en Historia, Vol. 37, № 1, Santiago, p. 174.

${ }^{47}$ Vergara, Alejandro. 1992. Principios y sistema del derecho minero: estudio histórico-dogmático, Santiago, Editorial Jurídica de Chile, p. 48.

48 Albert Cameron Burrage nació en Ashburnham, Massachusetts, el 21 de noviembre de 1859, estudió en Harvard obteniendo una Licenciatura. Pero su interés se desarrolló en las empresas mineras y también en la filantropía, donando los fondos para construir el Hospital Burrage para niños lisiados en Boston. Durante la Primera Guerra Mundial donó suficiente dinero para ayudar al país en el transcurso de la conflagración. Ver The Burrage House. 2000. Study Report, Landmarks Commission, Boston, Environment Department, p.4.

49 O'Connor, Harvey. 1937. The Guggenheims. The Making of an american dynasty, New York, Covici, Friede Publishers, pp. 347. 
No quepa duda que estas sociedades fueron creadas bajo el alero de las múltiples historias y relatos de pirquineros, de los baqueanos que, de pronto vistas las dificultades técnicas, tecnológicas y económicas, solo les quedaba soñar con encontrar y explotar la veta cuprífera, por tales razones fueron cediendo sus pertenencias.

El 11 de enero de 1912, en la ciudad de New Jersey, condado de Hudson, se constituyó la empresa The Chile Exploration Company ${ }^{50}$ con domicilio en 15 Exchange Place ${ }^{51}$.

Planteado el proyecto, realizadas las organizaciones corporativas, listas las planificaciones, dispuestos los recursos, comenzó la inmigración de variados ingenieros desde los Estados Unidos hacia la montaña roja de Chuquicamata, entre ellos Edwin Berry y Walter Perkins ${ }^{52}$ quienes, desde abril de 1912, se encargaron de los trabajos de perforación para principiar el mayor proyecto minero que conociera Chile una vez superada la Guerra del Pacífico. Estos ingenieros también estuvieron a cargo de proyectar la cimentación de la planta de tratamiento de óxidos de cobre, el trazado del ferrocarril, la apertura de los primeros "bancos" o áreas de explotación open pit, consistentes en la extracción a "cielo abierto", marcando una ruptura con el antiguo método extractivo a través de túneles y pirquenes ${ }^{53}$.

Paralelamente, la compañía comenzó un proceso de compra de la totalidad de las pertenencias mineras que merodeaban el sector, ejerciendo una exclusión a todo proyecto minero anterior a la norteamericanización cuprífera de Chuquicamata. Se calculó alrededor de 120 pertenencias o concesiones ${ }^{54}$. Simultáneamente el reputado ingeniero químico, civil y

50 El directorio quedó compuesto por Daniel Guggenheim, presidente; Albert Burrage, vicepresidente; Murry Guggenheim, vicepresidente; Harry Guggenheim, vicepresidente; William C. Potter, vicepresidente; C. K. Lipman, secretario; W. E. Bennett, asistente secretario; Leopold Fredrick, tesorero; M. M. Van Keuren, contralor; Philio Brasher, agente de empleo; O. L. Myers, auditor general; G. G. Thomson, agente de compras (O'Brien, Thomás. 1989. "Rich beyond the dreams of avarice: The Guggenheim in Chile", en Business History Review, № 63, Cambridge, pp. 123). Asociados a la familia Guggenheim estaban Benjamín Tracy, Frank Smith y James Sullivan, quienes figuraron como interpósitas personas. Tan pronto se realizó la adquisición y la organización de la empresa que, "el Sr. Fred Hellman, quien fue nombrado especialmente gerente general de la empresa, llegó al terreno con sus ayudantes el 4 de febrero de 1913" (Revista Ingeniería Internacional. 1922. "El mineral de Chuquicamata", Tomo 7, № 5, Nueva York, p. 298).

${ }^{51}$ The Chile Exploration Company se constituyó como agencia, por tal razón figura como una entidad controlada por otra sociedad: por Chile Copper Company, también creada en 1912 en EE.UU., pero en el Estado de Maine. Entonces, en Chile, en Chuquicamata, operaba The Chile Exploration Company, pero para el mundo la dueña de la mina era el holding Electrolytic Copper, cuyas acciones y mercado de capitales se transaban en Wall Street. Ver: O'Brien, Thomás. 1989. "Rich beyond the dreams of avarice: The Guggenheim in Chile", en Business History Review, № 63, Cambridge, pp. 122-159. Cabe indicar que, en 1916, se dejó de hablar de Guggenheim e Hijos siendo reemplazado por Guggenheim Bros. Este cambio realizado en los EE.UU. se debió a un pleito intrafamiliar por las futuras reparticiones de las ganancias (Gutiérrez, Eulogio. 1926. Chuquicamata, Tierra Rojas. Historia y monografía, Santiago, Editorial Nascimento, pp. 86).

52 Martínez, Gerardo. 1993. Orígenes y desarrollo de Chuquicamata, pp. 25.

53 Morel, Enrique. 1990. The Chuquicamata Complex. In Surface mining, ed. Kennedy, Bruce. 1990., Littleton, Colorado, Society for Mining, Metallurgy and Exploration, Inc. (U.S.), p. 1140.

54 Martínez, Gerardo. 1993. Orígenes y desarrollo de Chuquicamata, p. 35. 
metalúrgico Elias Cappelen Smith, fue el que tuvo a su cargo la dirección de las instalaciones de la gran planta de beneficio de Chuquicamata ${ }^{55}$. Por aquella época se encontraban trabajando en el mineral 600 obreros, de los cuales 450 eran chilenos $^{56}$.

Este proceso de compra y supresión de terceros, muchos de ellos chilenos, llega a su fin en julio del año 1913. Este proceso pudo ser llevado a cabo a través de Duncan Fox y el Banco Alemán Transatlántico. The Chile Exploration Company no adquirió ninguna pertenencia a su nombre, sino que lo hizo recién en el año 1920, cuando la Compañía Minera Zuleta vendió tardíamente sus pertenencias ${ }^{57}$.

En este transcurso se realizan las gestiones para acceder a concesiones o arrendamiento de terrenos y poder emplazar las instalaciones mecánicas y logísticas, en estas gestiones Duncan Fox actuaba como representante. En la obtención de esas concesiones y arriendos, destaca el acceso alquilado de 2.107 hectáreas de terrenos fiscales al sur de la mina de Chuquicamata ${ }^{58}$. Dicho arrendamiento fue sustancial para excluir del proyecto a cualquier tercero en la zona. Se añade la autorización para construir un ferrocarril de Chuquicamata a Mejillones, en 1913, aunque dicho proyecto nunca se concretó. En Tocopilla se gestionó el arrendamiento de los terrenos fiscales para implementar una vanguardista termoeléctrica en la Península de Algodonales ${ }^{59}$. Otros procesos relevantes son las concesiones para el uso de agua y la construcción, durante los años 1913 y 1914, de la Planta para el tratamiento de los minerales de cobre oxidados. Además, la implementación de todo el complejo industrial que permitió la explotación del yacimiento y el beneficio de los minerales. Esto llevaría adicionado una zona para el depósito de relaves. Adicionando una planta de óxidos con capacidad para 10.000 toneladas diarias; una fundición para 170 toneladas métricas compuesta por un horno reverbero con rueda de moldeo; además se implementó una casa electrolítica, una refinería y una planta de lixiviación para el tratamiento de minerales de baja ley ${ }^{60}$. Estas implementaciones permitieron extraer gran volumen de mineral oxidado con una ley de aproximadamente $1,75 \%$ de cobre.

Otros factores relevantes en este proceso fue la llegada de poderosas palas a vapor, "que son las mismas que se emplearon en las obras de construcción del Canal de Panamá, y que la

\footnotetext{
55 Morel, Enrique. 1990. The Chuquicamata Complex. In Surface mining, ed. Kennedy, Bruce. 1990., Littleton, Colorado, Society for Mining, Metallurgy and Exploration, Inc. (U.S.), p. 1141.

${ }^{56}$ Collao, Juan. 2001. Historia de Tocopilla, p. 256.

57 Orellana, Luis. 2004. "La lucha de los mineros", en Historia, p. 181.

58 Ibíd., p. 188.

59 Galaz-Mandakovic, Damir. 2017. "Turbinas y electricidad para la mina, lámparas a parafina para la población: crónica de una asimetría del capitalismo minero en Tocopilla (1914-1942)", en Estudios Atacameños № 54, San Pedro de Atacama, pp. 179-200; Galaz-Mandakovic, Damir. 2020. "The Guggenheim process. Innovaciones y contrapuntos de un sistema técnico y de transporte en la industria del salitre en el Departamento de Tocopilla (Chile, 19261949)". Revista de Historia, Concepción, № 27, vol. 2, pp. 175-209.

60 The farmer and mechanic [en Adelante TFAM] (Raleig), 29 de septiembre de 1914.
} 
Chile Exploration adquirió en licitación pública" ${ }^{11}$ (Figura 5). Marcial Figueroa dijo en 1928: "Alrededor de veinte palas eléctricas ejecutan el trabajo de excavaciones. Tres grandes palas eléctricas con un largo mástil llamadas 'Tipo Revolución completas' están equipadas cada cual con una cuchara de gran capacidad para cargar los carros con asombrosa rapidez. Las restantes son de menor capacidad y pueden operar en los cortes sin necesidad de rieles, éstas están provistas de un sistema de arrastre especial" ${ }^{62}$.

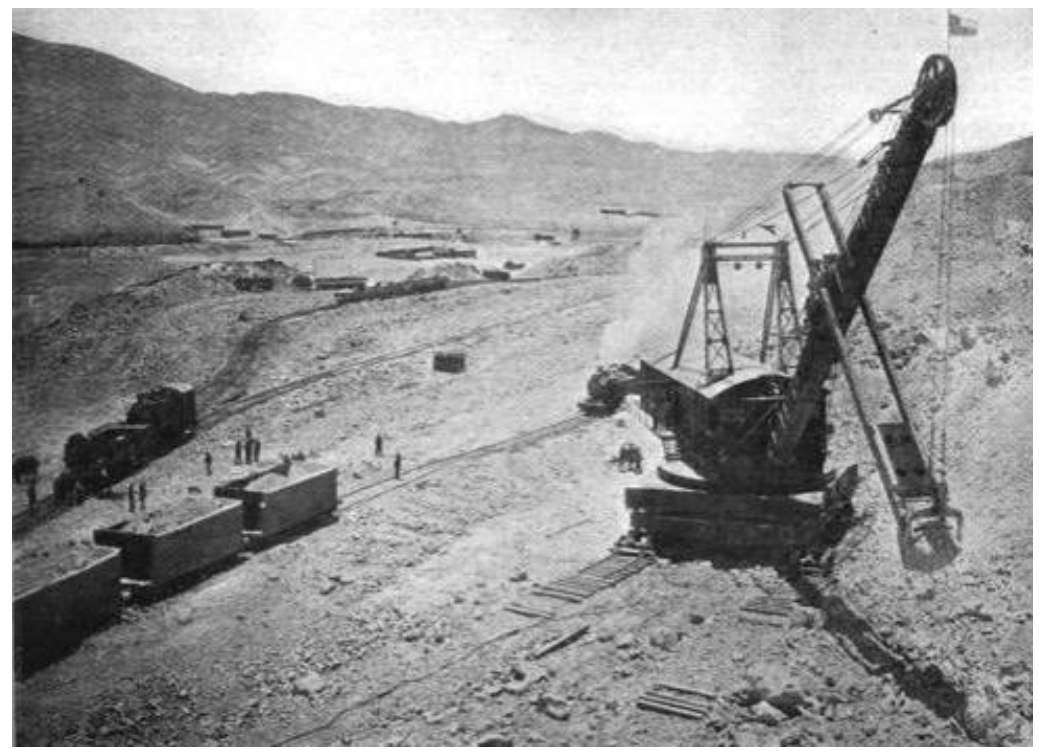

Figura 5. La mina de Chuquicamata en su etapa industrial open pit en 1920. Se aprecia la famosa pala, la misma maquinaria que participó en la construcción del Canal de Panamá. Fuente: Revista Ingeniería Internacional. 1922.

"El mineral de Chuquicamata", Tomo 7, № 5, Nueva York.

En términos generales, la planta estaba dividida en 16 departamentos ${ }^{63}$. Sin duda que el papel de los ferrocarriles instalados en la mina fue un factor fundamental para el transporte del material conseguido a través de potentes tronaduras, "sin ferrocarriles, Chuquicamata y EI Teniente no habrían sido ni la sombra de lo que son" ${ }^{\prime 64}$, comentó en 1923 el abogado y experto en minería Santiago Macchiavello.

Si destacamos algunas de las instalaciones, podemos mencionar la Vaciadora Eléctrica, sector en donde se extraía el mineral de los carros que bajaban de la mina, mediante un vuelco

\footnotetext{
61 Illanes, Guillermo. 1915. Mineral de Chuquicamata de la Chile Exploration Company inaugurado el 18 de mayo de 1915. Informe elevado al Supremo Gobierno, Santiago de Chile, Imprenta Universitaria, p. 9.

62 Figueroa, Marcial. 1928. Chuquicamata: la tumba del chileno, p. 40.

63 lbíd., p. 49.

64 Macchiavello, Santiago. 1923. El problema de la industria del cobre en Chile y sus proyecciones económicas y sociales, Santiago, Imprenta Fiscal de la Penitenciaría, p. 77.
} 
electromecánico, cayendo sobre una ancha correa transportadora. También estaban los Trituradores, sector molienda del metal: "cada trituradora puede triturar de 2 mil a 2 mil 500 toneladas por hora" ${ }^{65}$. Agréguese los Estanques de lixiviación, que recibían el metal triturado que provenía desde las trituradoras para la total extracción de sus sustancias por la función del ácido sulfúrico.

Otro sector importante era la conocida Casa verde o Casa de los estanques, departamento que recibía en pequeños depósitos el cobre en estado líquido, el cual provenía desde los estanques de lixiviación en donde se obtenía el cobre electrolítico en planchas. También estaba la Casa colorada, departamento que realizaba la conmixtión de la sobra de la Casa verde con las de la precipitación y con el cobre granulado que provenía de la fundición de cobre. "El área de Precipitación, permitía el tratamiento de los fierros y latas viejas del cobre que quedaba en el ácido sulfúrico después de haber sido empleado en la Casa verde" ${ }^{\prime 66}$. Además, se acometió la instalación de la sección llamada Stock de fundentes, unidad en donde eran llevadas las borras de la Casa verde y de la Casa colorada, así eran elaboradas en un horno de viento. La Fundición de Ánodos, era el departamento en donde se fabricaban las pilas que habían de colocarse dentro de los estanques para obtener el cobre electrolítico en la Casa Verde. Por su parte, la Fundición de cobre permitía la formación del cátodo: "después de algunas horas dentro del depósito electrolítico y donde se produce el cobre en barras, que ha de ser embarcado al exterior como también donde se granula el cobre que va a enriquecer las borras de la casa colorada" 67 .

El financiamiento del proyecto en Chuquicamata fue posible gracias a la emisión de 15 millones de dólares por parte de Chile Copper Company de Delaware (Tabla 2).

Tabla 2

Inversiones estimadas por The Chile Exploration Company para desarrollar el proyecto minero

\begin{tabular}{|c|c|}
\hline Inversión & Ítem \\
\hline US\$3,5 millones & Campamento en Chuquicamata \\
\hline US\$3,5 millones & Termoeléctrica en Tocopilla \\
\hline & Instalaciones industriales \\
US\$ 8 millones & Habilitación de la mina \\
& Ferrocarril \\
& Provisión de agua \\
\hline
\end{tabular}

Fuente: Elaboración propia a partir de: Martínez, G. 1993. Orígenes y desarrollo de Chuquicamata bajo la Chile Exploration Company. Santiago de Chile: Ediciones Revista Universitaria.

De este modo, Chuquicamata se transformó en un relevante centro que operaba con una producción a gran escala, "superior a Riotinto en España, a la Valenciana en Méjico, a Cerro de

\footnotetext{
65 Figueroa, Marcial. 1928. Chuquicamata: la tumba del chileno, p. 83.

66 lbíd., p. 51.

67 Ídem, p.51.
} 
Pasco en el Perú, a Kermecott en Alaska y a Inspiration en Arizona" ${ }^{68}$. Así, en el decir de Gutiérrez y Figueroa, Chuquicamata se convirtió en un mineral de excelencia, "al soplo de los capitales de la empresa yanqui que soliviantó la sierra sin horadarla para extraerle y beneficiarle el cobre ubérrimo de sus entrañas" ${ }^{69}$.

El diario estadounidense Mohave County Miner (Arizona) comunicaba en mayo de 1914 que, para acoger a los obreros, la empresa estaba construyendo "una ciudad" que contendría: "entre otros edificios un cuartel de soldados, dos escuelas públicas, un palacio de justicia y un edificio de telégrafos y correos, un teatro, un hospital, una cuarentena pública, una iglesia protestante y una iglesia católica, un salón de música para trabajadores y una biblioteca pública" 70 . El diario reparó en el detalle de la segregación: "La ciudad constará de dos secciones, una para extranjeros y otra para nativos. Probablemente será la mejor ciudad industrial de América del Sur"71. Por su parte, el diario Norwich Bulletin de la ciudad de Norwich, mencionó en noviembre de 1915: "Ahora hay alrededor de 350 norteamericanos y europeos y más de 3.000 nativos alojados en la propiedad (...) La vigilancia la realiza una compañía de carabineros de la policía montada de Chile, que tiene alojamiento en el campamento" ${ }^{72}$.

\section{Bolivianos en la etapa industrial de la mina}

Con el proyecto estadounidense, la gravitación migratoria fue intensa. Si bien el censo de 1895 invisibilizó a Calama y Chuquicamata por causa de ser "aldeas de poca importancia" ${ }^{73}$, hacia 1917 ya había 9.287 habitantes. Un año después, había 11.439 habitantes, distribuidos entre hombres (5.908), mujeres (2.339) y niños (3.192) ${ }^{74}$. Sin embargo, el censo de 1920 entrega una cifra menor: 9.715 habitantes. Según Macchiavello, hacia 1920, había 3.979 obreros $^{75}$. En ese escenario, podemos ver la evolución demográfica ascendente en Chuquicamata hasta 1952, situación numérica que contrasta con la evolución de Calama (Gráfico 4).

La percepción chilena sobre la migración boliviana en Chile era muy despreciativa. Una serie de imaginarios xenófobos y racistas circulaban por los centros mineros y también en algunos diarios. El diario de Antofagasta El Abecé, comentaba dichas semánticas que hablaban de que "el peón boliviano (...) era semisalvaje, de raza inferior, y tan barato que hacia descender los salarios". Distinguiendo entre las etnias aymaras y quechuas, ésta última retratada como

\footnotetext{
68 Gutiérrez, Eulogio y Marcial Figueroa. 1920. Chuquicamata: Su grandeza y sus dolores, p. 20.

69 Ibídem, p. 20.

${ }^{70}$ Mohave County Miner (Arizona) 9 de mayo de 1914.

71 Ídem.

72 Norwich Bulletin (Norwich), 20 de noviembre de 1915.

73 Oficina Central de Estadística. 1900. Sétimo Censo jeneral de la población de Chile levantado el 28 de noviembre de 1895, Valparaíso, Imprenta del Universo de Guillermo Helfman, p. 95.

${ }^{74}$ Chile Copper Company. 1920. First annual report of the Chile Copper Company, New York, Ed. The Chile Exploration Company, p. 17.

${ }^{75}$ Macchiavello, Santiago. 1923. El problema de la industria del cobre en Chile, p. 160.
} 
"menos fuerte y de menor talla que el aymara, cuya lengua es dulce y nasal, la del otro áspera y gutural"76.

En agosto de 1919, el diario boliviano La Verdad (La Paz) comentó sobre los modos de reclutamiento de obreros bolivianos, indicando que habían detectado a un encargado de estar remitiendo desde Bolivia para Chuquicamata a "todo trabajador que acepte sus promesas". Para dichos propósitos, el diario denunciaba la estrategia del enganchador para no ser notado: "este agente en tráfico humano, los remite en fracciones de a 2 y 4 diariamente, cargamentito que nos envía desde la altiplanicie, algunos de esos denodados patriotas que antes de darle preferencia a sus hermanos de miserias, recurren al comercio humano disimuladamente al mercado boliviano" ${ }^{77}$.

\section{Gráfico 4}

Evolución demográfica de Chuquicamata y Calama entre 1907 y 1952

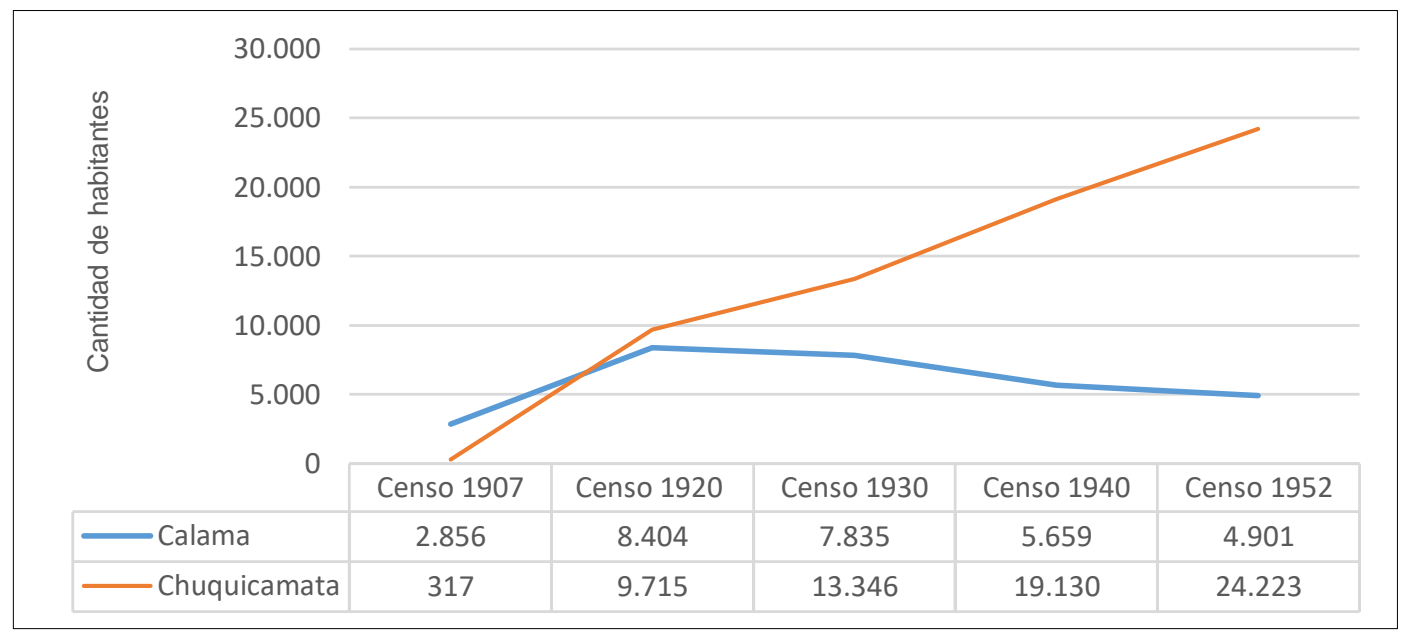

Fuente: Elaboración propia según los respectivos censos de población implementados por la Dirección General de Estadísticas (censo de 1907, 1920 y 1930), por el Servicio Nacional de Estadísticas y Censos (Censos de 1940, 1952).

El matutino La Verdad ( $L a \mathrm{Paz}$ ) indicaba que nadie se preocupaba de aquel "atentado delictuoso", alertando a los trabajadores sobre este "comerciante de incautos". La nota, que era firmada por "Un Roto", era de un chileno nacionalista que a la vez se quejaba sobre la mano de obra boliviana que supuestamente llegaba a Chile a desvalorizar el trabajo de los chilenos. En esas circunstancias, el articulista se preguntaba: "Por qué no traen peones yanquis de esos que ganan 5 y 6 dólares por días? No, de esos no traerán, más les conviene hacer venir de esos

\footnotetext{
76 El Abecé, (Antofagasta) [en adelante ABC], 19 de febrero de 1924.

77 La Verdad (La Paz) [en adelante LAP], 22 de agosto de 1919.
} 
más baratos, que no saben ápices de organización, que a igual que nosotros aceptan lo primero que nos ofrecen..." ${ }^{78}$.

Coincidentemente, a los pocos días el diario El Tiempo (La Paz), publicaba un aviso de la administración del Ferrocarril de Antofagasta a Bolivia (FCAB), el cual indicaba que, según la nueva ley de residencia del Gobierno de Chile, las autoridades exigirían pasaporte en Ollagüe (Figura 6). De este modo, la frontera buscó endurecerse.

Hacia la década de 1920, la condición social en la mina de Chuquicamata remitía a una escena multinacional, "allí se hablan por lo menos veinte idiomas" ${ }^{79}$, entre ellos el quechua "del altiplano con hedor a coca y a maní" ${ }^{80}$, mencionaba en 1920 Gutiérrez y Figueroa. Donde la convivencia era entre yugoslavos ${ }^{81}$, franceses, estadounidenses, chilenos, chinos, hasta "la india del Altiplano con sus amplias y repolludas polleras y su cría al hombro" ${ }^{82}$. No obstante, los bolivianos eran estigmatizados por el consumo de coca, siendo considerado un problema moral al igual que el alcoholismo: "La influencia del indio boliviano (...) ha sido la causa determinante de la propagación del uso de la cocaína, no en la forma de específicos previamente preparados, que usan los refinados del vicio, sino en una forma natural, por decirlo así, que consiste en la masticación de las hojas secas de la coca" ${ }^{83}$. En esa grafía, se construiría un problema y un causante, porque al saber lo que el consumo de la hoja de coca hace al estomago "insensible al hambre, la sed y la fatiga, razón por la cual su uso es frecuente" ${ }^{84}$, la coca produce "una anestesia (...) un problema de grandísimas consecuencias para el engrandecimiento de nuestra patria (...) peligro en las faenas mineras del norte" 85 .

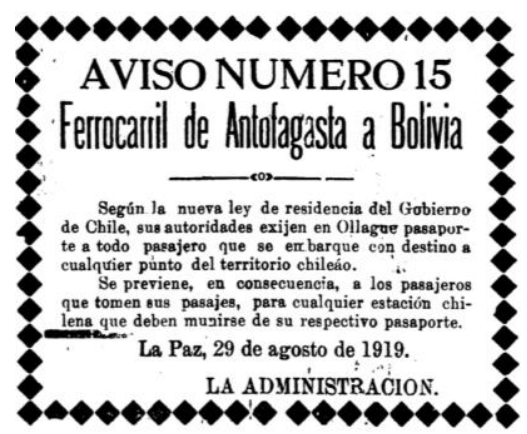

Figura 6: BAHALP. El Tiempo (La Paz), 29 de agosto de 1919.

\footnotetext{
78 LAP, 22 de agosto de 1919.

79 Gutiérrez, Eulogio y Marcial Figueroa. 1920. Chuquicamata: Su grandeza y sus dolores, p.179.

80 lbídem, p. 180.

81 Álvarez, Alejandro. 1999. Resumen de la historia de Calama, p. 61.

82 Gutiérrez, Eulogio y Marcial Figueroa. 1920. Chuquicamata: Su grandeza y sus dolores, p. 133.

83 Macchiavello, Santiago. 1923. El problema de la industria del cobre en Chile, p. 158.

84 Ídem.

85 Ídem.
} 
Más allá de aquellos juicios morales, Chuquicamata era un punto gravitacional para diversas migraciones: "los treinta y dos rumbos del horizonte trajeron a Chuquicamata gentes de los cuatro cardinales del planeta; gentes de todos los países, de todas las razas y condiciones" ${ }^{86}$. Así, entre portugueses, japoneses, argentinos, estaban los bolivianos que, "con Montes suspira por una ventanita en el Pacífico" ${ }^{87}$. Es decir, antes de las ampliaciones realizadas por Anaconda Company desde 1923, "al comienzo, parte no pequeña de los obreros, provenía de los altiplanos chileno y boliviano" 88 .

La participación laboral de los bolivianos se vio enfrentada a ciertas arbitrariedades por parte de los agentes estadounidenses que controlaban la mina y el campamento. Frente a algunos reclamos ante la obligación de trabajar los domingos en enero de 1917, tres familias de bolivianos fueron desalojados de sus domicilios en una madrugada, "por desobediencia a trabajar los domingos con el salario sencillo del día corriente" ${ }^{89}$.

Igualmente, obreros bolivianos trabajaron en precarias condiciones en la instalación de cañerías desde la bocatoma del río Toconce para abastecer con agua dulce al campamento. Gran parte de ellos sufrieron los efectos de las adversidades climáticas, produciéndose pulmonías fulminantes "contraída en los glaciales fríos de esta región al pie de la cordillera" 90. Según las informaciones que entregaron Gutiérrez y Figueroa, estos obreros manifestaron fuertes sangramientos, tos y dolores pulmonares, indicando que gran parte de ellos murieron. Uno de los trabajadores que eludió la muerte fue el boliviano Pedro Sandoval, quien pudo llegar a Calama "donde tuvo servicio médico atendido por su propia familia" 91.

Algunos bolivianos mecánicos y jornaleros, eran enviados a las calderas ${ }^{92}$. En 1923, el diario de Antofagasta El Abecé publicó una carta de trabajadores en Chuquicamata que hablaba sobre las sacrificadas condiciones laborales de los obreros que operaban en las calderas y casa de máquinas, secciones donde: "se trabaja a plena intemperie, y como ya se acerca y muy crudo invierno que en este mineral es insoportable por el tremendo frío y los grandes ventarrones, los operarios que trabajamos en estas dos secciones sufrimos horriblemente". Se agregaba que, en algunas ocasiones se tuvo que abandonar el trabajo por las adversas condiciones. Los trabajadores solicitaban techo en aquellas secciones de la empresa. Se temía por las enfermedades derivadas del extremo frío de altura, situación empeorada por la desatención de

\footnotetext{
${ }^{86}$ Gutiérrez, Eulogio y Marcial Figueroa. 1920. Chuquicamata: Su grandeza y sus dolores, p. 179.

87 Ibídem, p.179.

88 Martínez, Gerardo. 1993. Orígenes y desarrollo de Chuquicamata, p. 53.

89 Gutiérrez, Eulogio y Marcial Figueroa. 1920, Chuquicamata: Su grandeza y sus dolores, p.160.

90 Ibídem, p. 145.

91 Ibídem, p.133.

$92 \mathrm{ABC}, 13$ de junio de 1921.
} 
la empresa: "la compañía no nos paga nuestros sueldos por donde viene la ruina para nuestros hogares" $"$.

El 27 de marzo de 1920, la habitación del boliviano Encarnación Claro, en el sector llamado Campamento Nuevo, Los Adobes, fue allanada por orden de la guardia chuquicamatina por efecto de haber sido denunciado por otro boliviano por el ocultamiento de especies robadas a la empresa. De esa manera, el boliviano fue sorprendido con una "gran cantidad de cueros, zuelas y artículos adecuados a su oficio de zapatero, más una plancha eléctrica" ${ }^{94}$. A saber, de estos hallazgos, el boliviano no fue desalojado del campamento "con la natural sorpresa de todos (...) y sigue muy orondo y tranquilo trabajando en la empresa y habitando donde mismo se le encontró el cuantioso robo" ${ }^{95}$.

La escritora estadunidense Lilian Elwyn Elliott Joyce, quien visitó la mina en 1920, mencionó: "Chuquicamata emplea a unos 2.000 chilenos o bolivianos, con una pequeña pizca de trabajadores peruanos, alojados en condiciones que dejan algo que desear" 96 .

En su diagnóstico, agregó que muchas de las cabañas en las cuales vivían los obreros eran hechas con "plancha de hierro, con tabiques que dividen las habitaciones; los pisos son de barro y un sustituto opaco del vidrio oscurece el espacio de la ventana en demasiados casos". En ese sentido, también comentó que las casas de mejor clase eran insuficientes para los trabajadores nativos y advertía los descontentos potenciales por efecto de dichas condiciones habitacionales y segregaciones sociales y materiales. No obstante, detalla que los salarios eran más altos en comparación a los pagados en la mina El Teniente. Pero que el costo de vida era más alto en Chuquicamata, donde, por ejemplo, el carbón era casi desconocido, "se ve a las mujeres de los empleados cocinando sobre un brasero de carbón, o un fuego hecho con una planta umbelífera de la sierra (llareta), o unos trozos de madera traídos de largas distancias" ${ }^{\prime 2}$.

Ricardo Latcham al comentar sobre la diversidad cultural de Chuquicamata, enfatiza que un estudioso costumbrista tendría un dilatado campo de observación, partiendo por reseñar a lo que él llamó como la "indiada boliviana supersticiosa", colectivo migrante que según este autor "conserva aún viejos ritos y prácticas seculares que el cristianismo no ha podido desterrar de su ruda mentalidad"98. Y que, además, "esta gente profesa, a su manera, la religión católica; pero a menudo confunden los límites de la fe racional con los de las idolatrías, la superstición y el grosero fetichismo de los aborígenes" ${ }^{\prime 99}$.

\footnotetext{
${ }^{93} \mathrm{ABC}, 11$ de mayo de 1923.

${ }^{94}$ Gutiérrez, Eulogio y Marcial Figueroa. 1920. Chuquicamata: Su grandeza y sus dolores, p. 133.

95 Ídem.

96 Joyce, Lilian Elwyn. 1922. Chile today and tomorrow, New York, The Macmillan Company, p. 185.

97 Ibídem, p.186

98 Latcham, Ricardo. 1926. Chuquicamata. Estado yankee (Visión de la montaña roja), Santiago, Editorial Nascimento, p. 146.

${ }^{99}$ Ibídem, p.116.
} 
Este mismo cronista indica que los bolivianos consumían brebajes de baja calidad que eran expendidos por la pulpería: "Es famoso el vino infame que allí se expende y que hicimos analizar químicamente en una ocasión. Era puro campeche que se vende principalmente a la indiada boliviana"100.

Latcham también efectúa algunos comentarios sobre los barrios en los cuales habitaba la población boliviana, señalando que "la parte boliviana" de Chuquicamata estaba más arriba del sector denominado como Pueblo Hundido, enfatizando en que dicha agrupación de bolivianos "parecía un palomar gigantesco con sus casas minúsculas en forma de cubos". Latcham se refería al barrio conocido popularmente como Las Latas, "cuyo estado da una impresión muy desgraciada", detallando que el aspecto era "inferior" a Pueblo Hundido e incomparablemente peor que el barrio llamado Los Adobes, indicando que era necesario blanquear y pintar casi todas las habitaciones. En el desdeñoso comentario de Latcham se indica que "estos arreglos deben ser inferior en la parte boliviana, pues sus moradores no tienen idea alguna de los principios más elementales de la higiene" ${ }^{101}$. Por su parte Marcial Figueroa mencionó que Las Latas era un barrio conformado por casas de "dos piezas estrechas donde tiene que vivir una familia compuesta de varias personas"102, barrio que también fue conocido como el “Campamento boliviano"103. Se trataba de una casa dúplex con delgadas divisiones. El déficit de baños generaba múltiples discordias entre sus habitantes, considerando un saturado y paupérrimo alcantarillado ${ }^{104}$. Viviana Vilches señala que los habitantes de Las Latas "debían salir de sus casas para usar los servicios higiénicos que en ocasiones funcionaron por turnos" ${ }^{105}$, esto último en turnos para hombres y luego mujeres.

De esa manera, los bolivianos vivían en una comunidad segregada dentro de los campamentos de las minas de cobre "y mantienen un mundo cultural separado con sus propios clubes sociales, sociedades de ayuda mutua y clubes políticos" ${ }^{106}$. Allí las bolivianas vendían "las verduras a escondidas" ${ }^{\prime 107}$. Con casas que se llenaban de humo cuando se combustionaban las yaretas para cocinar o calefaccionar ${ }^{108}$.

\footnotetext{
100 lbíd., p.70.

101 Ibíd., p. 134.

102 Figueroa, Marcial. 1928. Chuquicamata: la tumba del chileno, p. 202.

103 Tapia, Gustavo. 2001. Chuquicamata, historia con nostalgia, Ediciones Parina, p. 107.

104 Ídem.

105 Vilches, Viviana. 2018. Chuquicamata. Evolución de la vivienda en el Campamento Nuevo. Santiago, Andros Impresores, p. 47.

106 Klubock, Thomas. 2001. Nationalism, race, and the politics of imperialism: Workers and North American capital in the Chilean copper industry. In Reclaiming the political in Latin American history: Essays from the North, ed. G. Joseph, 231-267. Durham, NC: Duke University Press, p. 240.

107 Vilches, Viviana. 2018. Chuquicamata. Evolución de la vivienda en el Campamento Nuevo. Santiago, Andros Impresores, p. 49.

108 Ibíd., p. 47
} 
La población boliviana en la minería chilena era vista como subsidiaria en el sentido que realizaban trabajos que los chilenos no deseaban realizar, al menos así lo menciona Semper y Michels en 1908, quienes indicaron que en la industria del salitre se empleaban mineros bolivianos principalmente en "trabajos subterráneos i en calicheras mui profundas, porque los chilenos no se prestan tan fácilmente a esta clase de trabajos" ${ }^{109}$. Algo similar dijo Latcham: "En el mineral había una fuerte población de indios bolivianos, temibles competidores de los chilenos en sus trabajos de extracción, pues se contentaban con poco salario y no demuestran grandes exigencias materiales, por lo que a veces son preferidos por los capitalistas norteamericanos" ${ }^{110}$.

Los trabajadores bolivianos también se vieron involucrados en una de las principales tragedias: la explosión de dos carros cargados con dinamita del 25 enero de 1937, la cual tuvo un saldo de 53 muertos y más de 100 heridos. El diario La Nación (Santiago) identificó al ciudadano boliviano Juan Abasto Antezana, quien era casado, adicionando a Benigno Flores y Carlos Verdejo como heridos ${ }^{111}$.

Así, los bolivianos residían en el barrio más precario del campamento, en Las Latas, que oficialmente era denominado como Townsite Type D-2 por parte de los estadounidenses. Barrio caracterizado por la estrechez y el hacinamiento, por la escasez de agua, sin baños, sin patio, conviviendo con animales y con escasos espacios de privacidad ${ }^{112}$.

\section{Caracterización de la migración boliviana entre 1881 y 1942}

En la caracterización global de la migración boliviana en Chuquicamata durante los años 1881 y 1942, podemos establecer los principales datos que la definen, en especial a las comunidades de origen, género, estado civil, edad y oficios.

\section{Orígenes de los bolivianos y bolivianas}

Sobre el lugar de origen de los bolivianos, es posible advertir una gran diversidad de localidades ( $n=24)$. No obstante, la ciudad de Cochabamba destaca con el 49,6\%. Le siguen, de lejos, Oruro $(9,1 \%)$, Sucre $(7,4 \%)$, La Paz $(7,1 \%)$ y Potosí (5,7\%). El Departamento de Cochabamba poseía una población aproximada de 40.000 habitantes en el primer lustro de la década de $1920^{113}$. Se evidencia una movilidad marcada por la discontinuidad espacial o geográfica entre los espacios de origen y destino; es decir, se articulan dos territorios no colindantes. Situación que difiere con lo ocurrido a mediados de siglo, momento en que se atestiguan migraciones en zonas

\footnotetext{
109 Semper, E. y Michels, Wilhelm. 1908. La industria del salitre en Chile, Santiago, Imprenta Barcelona, p. 100.

110 Latcham, Ricardo. 1926. Chuquicamata. Estado yankee, p. 116.

111 La Nación (Santiago), 27 de enero de 1937.

112 Vilches, Viviana. 2018. Chuquicamata. Evolución de la vivienda en el Campamento Nuevo. Santiago, Andros Impresores, p. 47.

113 Mesa Gisbert, Carlos; De Mesa, Carlos, Gisbert, Teresa. 2007. Historia de Bolivia, La Paz, Editorial Gisbert, p. 417.
} 
contiguas o de inmediación territorial (entre altiplano boliviano y chileno) surgiendo una red migrante inscrita en economías familiares ${ }^{114}$.

Tabla 3

Lugar de origen, periodo de ingreso y cantidades de bolivianos y bolivianas que llegaron a

Chuquicamata

\begin{tabular}{|c|c|c|c|c|c|c|}
\hline \multirow[b]{2}{*}{$\begin{array}{l}\text { Lugar de origen en } \\
\text { Bolivia }\end{array}$} & \multicolumn{5}{|c|}{ Período de ingreso a Chuquicamata } & \multirow[b]{2}{*}{ Total } \\
\hline & $\begin{array}{c}\text { Etapa } 1 \\
1881-1884\end{array}$ & $\begin{array}{c}\text { Etapa } 2 \\
1885-1911\end{array}$ & $\begin{array}{c}\text { Etapa } 3 \\
1912- \\
1922 \\
\end{array}$ & $\begin{array}{c}\text { Etapa } 4 \\
1923-1942\end{array}$ & No indica & \\
\hline Camargo & & 1 & & & & 1 \\
\hline Cacachaca & & & 1 & & & 1 \\
\hline Carasa & & & 1 & & & 1 \\
\hline Chafani & & & & 1 & & 1 \\
\hline Cinti & & & 1 & & & 1 \\
\hline Ciuta & & & 1 & & & 1 \\
\hline Cochabamba & 1 & 45 & 44 & 84 & 1 & 175 \\
\hline Colca & & & 1 & & & 1 \\
\hline La Paz & & 6 & 11 & 8 & & 25 \\
\hline Oruro & & 5 & 16 & 11 & & 32 \\
\hline Potosí & & 4 & 9 & 6 & 1 & 20 \\
\hline Pulacayo & & 2 & & & & 2 \\
\hline Quillacollo & & 2 & 12 & 8 & & 22 \\
\hline Santa Cruz de la Sierra & & & 1 & 1 & & 2 \\
\hline Sipe Sipe & & & & 1 & & 1 \\
\hline Sacaba & & 1 & 1 & 1 & & 3 \\
\hline Sucre & & 8 & 14 & 4 & & 26 \\
\hline Tarata & 1 & & 1 & 1 & & 3 \\
\hline Tarija & & 4 & 1 & 1 & & 6 \\
\hline Tupiza & & 2 & 6 & 4 & & 12 \\
\hline Uyuni & & 4 & 6 & 4 & & 14 \\
\hline Otros & & & 1 & 2 & & 3 \\
\hline TOTAL & 2 & 84 & 128 & 137 & 2 & 353 \\
\hline
\end{tabular}

Fuente: Archivo Histórico Universidad Católica del Norte, Fondo Archivo de Extranjería del Registro Civil e Identificación de Antofagasta, migración boliviana 1879-1946. Elaboración propia.

114 Garcés, Alejandro; Moraga, Jorge; Maureira, Mauricio; Saavedra, Adrián. 2019. “Desbordando la Puna de Atacama. Movilidad, economías y etnicidad (1950 al presente)", en Cahiers des Amériques Latines, № 92, París, pp. 49-69. 
El diario El Abecé comentó sobre los cochabambinos: "que, por ser de la zona templada, tienen el color moreno. El cochabambino es a menudo de grande estatura (...) es sobrio, tiene mujeres propias, por tanto, no asiste a ese matadero del bolsillo, cuerpo y alma, llamado prostíbulo"115.

Notemos la presencia de migrantes provenientes de Quillacollo, una ciudad del Departamento de Cochabamba que se encuentra a tan solo 13 kilómetros de la capital departamental. En definitiva, las cinco principales ciudades suman el $78,8 \%$ del total de ingresos (Tabla 3).

Al ver que el Departamento de Cochabamba es la región que más emigrantes posee, cabe la pregunta natural sobre sus circunstancias y contexto, sobre el cual podemos indicar que, en el periodo de la posguerra, la zona sufrió una declinación de su rol de proveeduría agrícola (granos, frutas, harina, legumbres, hortalizas, también cueros) hacia diversos centros mineros entre ellos los campamentos de Pulacayo, Huanchaca y varias salitreras ${ }^{116}$, además de proveer diversas ropas para aquellas minerías ${ }^{117}$.

Por efecto de la citada beligerancia, el comercio boliviano hacia Chile fue bloqueado. Además, por causa del Protocolo Complementario de 1885, se aplicaron franquicias aduaneras favorables para que variados productos ingresaran a Bolivia desde Chile a muy bajo precio ${ }^{118}$ afectando a toda una economía regional ${ }^{119}$. Este impacto se aceleró a través de la penetración del Ferrocarril Antofagasta a Bolivia (FCAB) desde 1890, hito que densificó la participación económica de la naciente ciudad de Uyuni y Oruro desde 1892, centros que dinamizaron migraciones internas, deviniendo importantes aumentos demográficos.

Dicha crisis económica en el Departamento de Cochabamba, llevó a que varios hacendados fragmentaran sus propiedades agrícolas, surgiendo los llamados parceleros, quienes eran pequeños propietarios de la tierra. Entre los años 1908 y 1916 se contabilizaron 28.550

\footnotetext{
${ }^{115} \mathrm{ABC}, 19$ de febrero de 1924.

116 Rodríguez, Gustavo. 1990. "Estado nacional, mercado interior y élites regionales", pp.11-32; Henríques, Rosario. 2015. Análisis de los niveles de vida", Tesis para optar al grado de Doctora en Economía en la Facultad de Ciencias Económicas y Empresariales, Departamento de Economía Aplicada e Historia Económica, Madrid, UNED, p.197; Galaz-Mandakovic, Damir. 2016. "Industrialización minera, urbanización e innovación en las relaciones sociales en el sudoeste del altiplano boliviano: el caso de la Compañía Huanchaca de Bolivia (1834-1930)", en Estudios Atacameños, № 52, San Pedro de Atacama, pp. 153-175.

117 La zona de Cochabamba proveía la ropa para los procesos de lixiviación del caliche, tales como las fajas, polainas, pantalones encayapados y los zapatones para los desripiadores. Ver González Miranda, Sergio y González Pizarro, Sergio. 2020. "La frontera que se difumina y endurece. El espacio de influencia del salitre y los flujos transfronterizos Chile- Bolivia (1880-1930)", en Revista. Ciencia y Cultura, Vol. 24, № 44, La Paz, pp. 120.

118 Por citar una muestra, podemos ver que el costo de la harina cochabambina puesta en La Paz era $25,6 \%$ más cara de la que provenía desde Antofagasta y $17,6 \%$ más cara respecto de la harina que llegaba desde Mollendo. Asimismo, perdían sus mercados la producción de tocuyos y diversos cereales. Ver: Henríques, Rosario. 2015. Análisis de los niveles de los niveles de vida, p. 42.

119 Rodríguez, Gustavo. 2014. Capitalismo, modernización y resistencia popular 1825-1952, La Paz, Bolivia, Vicepresidencia del Estado de Bolivia-Centro de Investigaciones Sociales, p.335.
} 
propiedades, lo que significaba prácticamente una triplicación de la cantidad de propiedades registradas a fines del siglo XIX ${ }^{120}$. A la crisis, se sumaron periodos de densas sequías, afectando la producción de cereales ${ }^{121}$. En esas circunstancias, la emigración hacia centros mineros de estaño, plata y cobre, no se dejó esperar. Fue el mismo ferrocarril FCAB el vehículo de ingreso para muchos bolivianos.

Hacia la década de 1920, la zona de Cochabamba vive una revivificación por efecto de la nacionalización de la industria alcoholera, decisión del presidente José Manuel Justiniano Gutiérrez Guerra. La nacionalización exigió una mayor explotación de las cañas de azúcar y de los maizales de los valles cochabambinos promoviendo, además, la producción de las destilerías. Dicho decreto indicaba en su Art. 1: "queda prohibida la importación de alcoholes y aguardientes extranjeros" 122 .

En el año 1917 se consumía un 1\% de maíz. Entre 1923 y 1925, aumentó a un 37\% ${ }^{123}$. Sin embargo, la economía cochabambina sufriría las oscilaciones propias del capitalismo, siendo también apremiada por el contrabando, el alza de los fletes y la competitividad internacional.

\section{Género y estado civil}

En cuanto a la relación entre género, estado civil y año de ingreso de migrantes bolivianos, se identifica una concentración cerrada de hombres solteros entre los años 1915 y 1922 y de mujeres solteras entre 1918 y 1922 (Gráfico 5). Hombres y mujeres casados presentan concentraciones más amplias, pero cuyas líneas medias se sitúan en 1920. Es interesante destacar las concentraciones de viudos y viudas, que se sitúan cronológicamente mucho antes: una media para hombres en 1910 y para mujeres en 1900.

La relación entre género, estado civil y edad nos ayuda a profundizar la relación precedente. Observamos una relativa homogeneidad de las edades entre hombres y mujeres, con una media de edad de solteros y solteras menor que la media de casados y viudos (Gráfico 6). Igualmente, las concentraciones de edad son más cerradas para los solteros y solteras, y mucho más amplias para los viudos y viudas. Los datos señalan que se trata de una migración principalmente de adultos entre 20 y 30 años, las mujeres solteras presentan una media de edad más joven, la cual se sitúa en los 18 años.

\footnotetext{
120 Rodríguez, Gustavo. 1990. "Estado nacional, mercado interior y élites regionales", p. 17

121 Henríques, Rosario. 2015. Análisis de los niveles de vida, España, p. 42.

122 Archivo de la Gaceta Oficial del Estado Plurinacional de Bolivia, Lei del 23 de enero de 1918, Ministerio de Hacienda, José Gutiérrez Guerra, presidente de Bolivia.

${ }^{123}$ Rodríguez, Gustavo. 1990. "Estado nacional, mercado interior y élites regionales”, pp.11-32.
} 
Gráfico 5

Año de ingreso por género y estado civil

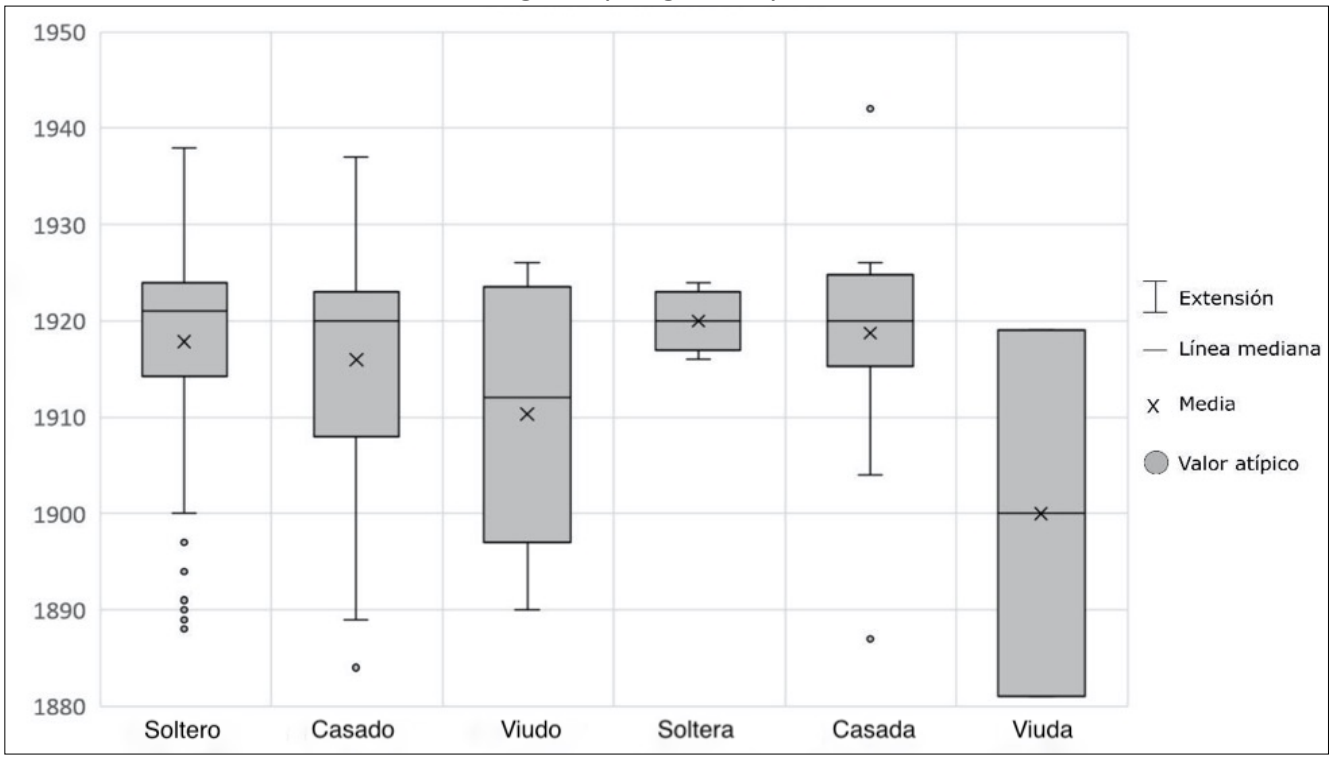

Fuente: Archivo Histórico Universidad Católica del Norte, Fondo Archivo de Extranjería del Registro Civil e Identificación de Antofagasta, migración boliviana 1879-1946. Elaboración propia.

Gráfico 6

Edad por género y estado civil

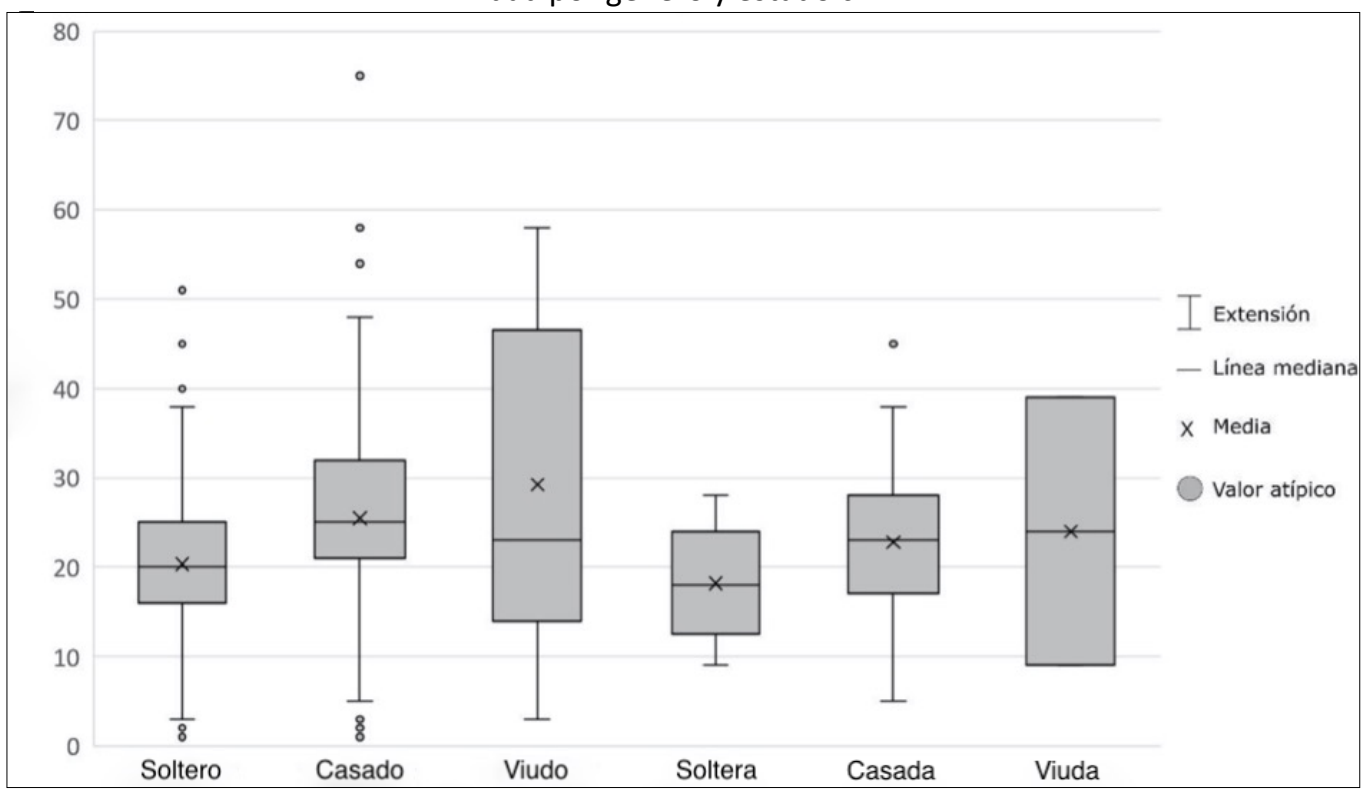

Fuente: Archivo Histórico Universidad Católica del Norte, Fondo Archivo de Extranjería del Registro Civil e Identificación de Antofagasta, migración boliviana 1879-1946. Elaboración propia. 


\section{Oficios y/o profesiones}

En los datos sobre profesión u oficio de los migrantes bolivianos según el periodo de ingreso a Chuquicamata, se evidencia una gran diversidad, si bien los jornaleros dominan dentro del total, una mirada fina a las distinciones por género muestra una presencia masculina significativa de jornaleros (18\% del total de hombres), mecánicos $(16,1 \%)$, sastres $(14,3 \%)$, carpinteros $(9,6 \%)$, empleados $(7,1 \%)$ y electricistas $(5,6 \%)$.

En el caso de las mujeres, la ocupación mayormente representada es labores del sexo (51,6\% del total de mujeres) (tabla 4). Destaquemos que el $41,6 \%$ del total general corresponde a profesiones u oficios dentro del sector terciario de la economía, es decir a servicios subsidiarios de la minería o a oficios asociados a la vida cotidiana dentro de un company town como Chuquicamata.

Tabla 4

Profesión u oficio por género según el periodo de ingreso a Chuquicamata

\begin{tabular}{|c|c|c|c|c|c|c|}
\hline \multirow{2}{*}{$\begin{array}{c}\text { Profesión u } \\
\text { oficio }\end{array}$} & \multicolumn{5}{|c|}{ Período de ingreso } & \multirow[b]{2}{*}{ Total } \\
\hline & $\begin{array}{c}\text { Etapa } 1 \\
1881-1884\end{array}$ & $\begin{array}{c}\text { Etapa } 2 \\
1885-1911\end{array}$ & $\begin{array}{c}\text { Etapa } 3 \\
1912-1922\end{array}$ & $\begin{array}{c}\text { Etapa } 4 \\
1923-1942 \\
\end{array}$ & No indica & \\
\hline Hombre & 1 & 80 & 114 & 125 & 2 & 322 \\
\hline Agricultor & & & 1 & & & 1 \\
\hline Albañil & & 1 & 3 & 4 & & 8 \\
\hline Artesano & & & & 1 & & 1 \\
\hline Caballerizo & & & 1 & & & 1 \\
\hline Calderero & & & 2 & & & 2 \\
\hline Carnicero & & & 1 & & & 1 \\
\hline Carpintero & & 6 & 10 & 15 & & 31 \\
\hline Carretero & & 1 & & & & 1 \\
\hline Carrocero & & & & 1 & & 1 \\
\hline Chofer & & 1 & 2 & 2 & & 5 \\
\hline Comerciante & & 1 & & & & 1 \\
\hline Contador & & & & 1 & & 1 \\
\hline Dibujante & & 1 & & & & 1 \\
\hline Electricista & & 4 & 6 & 7 & 1 & 18 \\
\hline Empleado & & 6 & 9 & 8 & & 23 \\
\hline Estudiante & & & 1 & & & 1 \\
\hline Fogonero & & 1 & 3 & 1 & & 5 \\
\hline Fundidor & & & 3 & & & 3 \\
\hline Herrero & & 1 & & 1 & & 2 \\
\hline
\end{tabular}




\begin{tabular}{|c|c|c|c|c|c|c|}
\hline Jornalero & & 12 & 22 & 24 & & 58 \\
\hline $\begin{array}{c}\text { Labores de } \\
\text { casa }\end{array}$ & & & 1 & & & 1 \\
\hline Maquinista & & 1 & 4 & 2 & & 7 \\
\hline Mecánico & & 12 & 21 & 19 & & 52 \\
\hline Mensajero & & & 1 & & & 1 \\
\hline Minero & & 1 & 4 & 2 & & 7 \\
\hline Modista & & 1 & & & & 1 \\
\hline Motorista & & 1 & & & & 1 \\
\hline Músico & & 1 & & & & 1 \\
\hline No indica & & 2 & & & & 2 \\
\hline Operario & & 2 & 1 & 3 & & 6 \\
\hline Panadero & & 2 & & & & 2 \\
\hline Peluquero & & & 1 & 2 & & 3 \\
\hline Periodista & & & & 1 & & 1 \\
\hline Sastre & 1 & 16 & 12 & 16 & 1 & 46 \\
\hline Sombrerero & & 1 & & 4 & & 5 \\
\hline Talabartero & & 3 & 1 & & & 4 \\
\hline Tejedor & & & 1 & 1 & & 2 \\
\hline Telegrafista & & & & 3 & & 3 \\
\hline Tipógrafo & & & & 1 & & 1 \\
\hline Topógrafo & & & & 1 & & 1 \\
\hline Tornero & & & 1 & 2 & & 3 \\
\hline Trabajador & & & 1 & & & 1 \\
\hline Zapatero & & 2 & 1 & 3 & & 6 \\
\hline Mujer & 1 & 4 & 14 & 12 & & 31 \\
\hline Cocinera & & & 1 & & & 1 \\
\hline Comerciante & 1 & & & & & 1 \\
\hline Costurera & & 1 & & 1 & & 2 \\
\hline Empleada & & & 2 & 1 & & 3 \\
\hline Florista & & & 1 & & & 1 \\
\hline Jornalera & & 2 & & & & 2 \\
\hline $\begin{array}{c}\text { Labores de } \\
\text { casa }\end{array}$ & & & & 1 & & 1 \\
\hline $\begin{array}{c}\text { Labores del } \\
\text { sexo }\end{array}$ & & & 8 & 8 & & 16 \\
\hline Lavandera & & & 1 & & & 1 \\
\hline
\end{tabular}




\begin{tabular}{|c|c|c|c|c|c|c|}
\hline Modista & & 1 & & & & 1 \\
\hline Químico & & & & 1 & & 1 \\
\hline Sastre & & & 1 & & & 1 \\
\hline Total & 2 & 84 & 128 & 137 & 2 & 353 \\
\hline
\end{tabular}

Fuente: Archivo Histórico Universidad Católica del Norte, Fondo Archivo de Extranjería del Registro Civil e Identificación de Antofagasta, migración boliviana 1879-1946. Elaboración propia.

En ese marco, dentro de la categoría de alfabetización (Tabla 5), observamos que el 86,4\% de los migrantes señaló que sabía leer y escribir. La proporción es mayor en el caso de los hombres $(89,8 \%$ del total masculino) que en las mujeres (51,6\% del total femenino).

Tabla 5. Alfabetización por Género

\begin{tabular}{|c|c|c|c|c|c|c|}
\hline \multirow[b]{2}{*}{ Alfabetización } & \multicolumn{5}{|c|}{ Período de ingreso } & \multirow[b]{2}{*}{ Total } \\
\hline & $\begin{array}{c}\text { Etapa } 1 \\
1881-1884\end{array}$ & $\begin{array}{c}\text { Etapa } 2 \\
1885-1911 \\
\end{array}$ & $\begin{array}{c}\text { Etapa } 3 \\
1912-1922 \\
\end{array}$ & $\begin{array}{c}\text { Etapa } 4 \\
1923-1942 \\
\end{array}$ & No indica & \\
\hline Hombre & 1 & 80 & 114 & 125 & 2 & 322 \\
\hline No & & 7 & 10 & 16 & & 33 \\
\hline Sí & 1 & 73 & 104 & 109 & 2 & 289 \\
\hline MUJER & 1 & 4 & 14 & 12 & & 31 \\
\hline No & 1 & 2 & 8 & 4 & & 15 \\
\hline Sí & & 2 & 6 & 8 & & 16 \\
\hline Total & 2 & 84 & 128 & 137 & 2 & 353 \\
\hline
\end{tabular}

Fuente: Archivo Histórico Universidad Católica del Norte, Fondo Archivo de Extranjería del Registro Civil e Identificación de Antofagasta, migración boliviana 1879-1946. Elaboración propia.

\section{Redes y familias}

Por último, el número de parientes en Chile que fueron declarados por los nuevos migrantes ofrece una visión general de las relaciones sociales existentes entre ambos lados de la frontera (Gráfico 7). Solo una persona declaró no conocer a nadie, lo que demuestra la importancia de las redes de contactos familiares (o de amistades) para decidir a Chuquicamata como destino. El 83,6\% del total de personas declaró tener entre uno a tres parientes en Chile. Vemos aquí probablemente un indicio de la presencia significativa de personas de origen boliviano en Chile antes de 1881, quienes seguramente se vieron enfrentados a la imposición de una nueva frontera internacional que los categorizó como "extranjeros" y "migrantes" en los años de posguerra. 
Gráfico 7

Número de parientes en Chile por estado civil

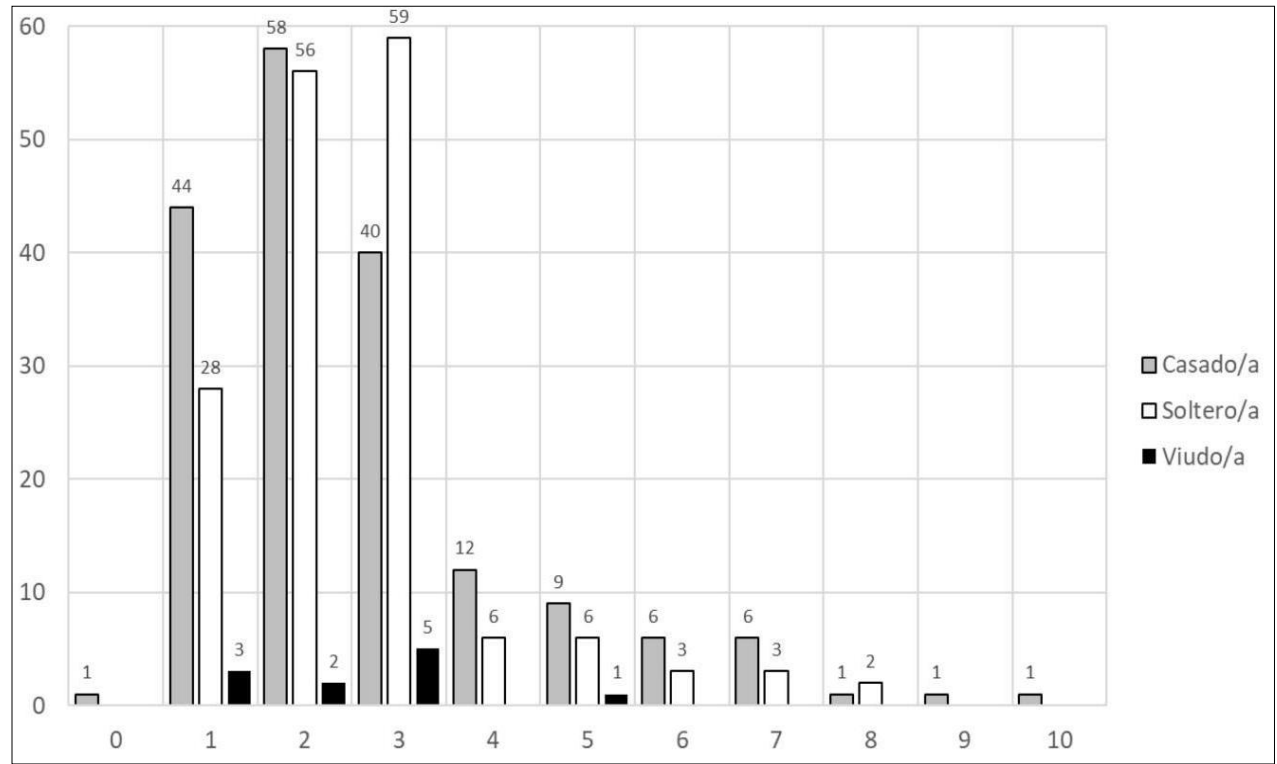

Fuente: Archivo Histórico Universidad Católica del Norte, Fondo Archivo de Extranjería del Registro Civil e Identificación de Antofagasta, migración boliviana 1879-1946. Elaboración propia.

En síntesis, los datos sobre la migración boliviana que tuvo como destino Chuquicamata y que fue registrada en los prontuarios del AHUCN, estuvo compuesta por una población principalmente urbana, masculina, alfabetizada y asociada a profesiones y oficios del sector terciario de la economía. Se trata de personas que ya contaban con redes familiares en Chile, que llegó en diferentes olas migratorias desde 1900 pero en gran número durante el primer lustro de la década de 1920.

\section{Tensiones, declive migrante y organización boliviana}

Como hemos advertido, la densificación de la migración boliviana estuvo presente desde la etapa preindustrial y aumentó en el período de la inicial industrialización, al menos en los primeros 10 años bajo dominio de los Guggenheim. Hemos apostillado que el descenso de migrante se correlaciona con el traspaso de la propiedad de la mina en el primer lustro de la década de 1920 y se condice con la densificación de la tensión entre chilenos y bolivianos, la cual se exacerbó durante la década de 1920 por razón de, "la estrategia de la empresa norteamericana de contratar a bolivianos (...) que se creía que eran más dóciles que los chilenos, con salarios más bajos, un método que había sido empleado por los británicos" ${ }^{124}$.

\footnotetext{
124 Klubock, Thomas. 2001. Nationalism, race, and the politics of imperialism: Workers and North American capital in the Chilean copper industry. In Reclaiming the political in Latin American history: Essays from the North, ed. G. Joseph, 231-267. Durham, NC: Duke University Press, p. 240.
} 
Desde aquel periodo, las actividades reivindicativas por parte de los obreros chilenos comenzaron a basarse en la legislación de 1924, año en que se creó la Dirección General del Trabajo (a través de la Ley $\mathrm{N}^{\circ}$ 4.053). Desde entonces, el reconocimiento y protección de derechos laborales fue ascendiendo. En 1928, a través del DS N 1.846, se aprobó el reglamento orgánico de la Inspección General del Trabajo, entidad que se ocupó de vigilar las condiciones laborales en cada una de las provincias. En 1931, un nuevo Código del Trabajo, significó la creación de sindicatos tanto de empleados como de obreros de la mina y de la Planta ${ }^{125}$.

En el decir de Francisco Zapata, las primeras exigencias de los sindicatos, tuvieron un fuerte rasgo nacionalista, en cuanto a la exigencia de contratar a chilenos como obreros, además de articular peticiones sobre los ambientes laborales, mejoramiento de los sueldos y "los derechos a presentar pliegos de peticiones, así como la necesidad de que los dirigentes cuenten con un fuero"126. Todo esto, según Thomas Klubock, fue generando "El antagonismo de los trabajadores chilenos con los bolivianos en Chuquicamata lo que provocó décadas de hostilidades nacionales y étnicas en el norte de Chile"127.

De esa manera, vemos que además del cambio de propiedad de la mina, el fortalecimiento laboral y los discursos de rechazo, hicieron que la migración boliviana disminuyera. Si los inicios industriales de Chuquicamata se correlacionaron con la precariedad del habitar, a medida que se ascendía en la calidad de vida, coincidentemente los migrantes bolivianos fueron desapareciendo (pero no del todo). Agreguemos a lo anterior, el endurecimiento de las

\footnotetext{
125 En el nuevo marco legal, los obreros y empleados tuvieron que disolver sus antiguas organizaciones y debieron participar en la nueva modalidad. El Sindicato Profesional de Empleados de la Chile Exploration Company de Chuquicamata, fue organizado desde el 16 de febrero de 1930, concretándose en 1931 la sindicalización. El 3 de septiembre de 1933 nació el Sindicado Industrial de la Termoeléctrica de Tocopilla. A los ocho años, los empleados subdividieron la organización y crearon el Sindicato de Empleados de la Chilex, el 22 de octubre de 1941. Estos hechos estaban inscritos en un proceso llevado a cabo en varias ciudades relacionadas con la explotación cuprífera, podemos citar las siguientes conformaciones: Sindicato Industrial Braden Copper Company, Sección Coya Pangal, fundado el 5 de septiembre de 1928. Sindicato Industrial de Obreros de la Chilex Exploration Company de Potrerillos, fundado el 3 de diciembre de 1932. Sindicato Profesional de Empleados Particulares de Braden Copper Company, Centro de Trabajo Sewell y Mina, fundado el 21 de junio de 1937. El Sindicato Industrial de Obreros de la Andes Copper Mining Company, Sección Barquito, fundado el 3 de marzo de 1939. Sindicato Profesional de Empleados Braden Copper Company, Centro de Trabajo Coya y Pangal, fundado el 15 de septiembre de 1939. Los empleados de la Andes Copper Mining Company and Potrerillos Railway, crearon el Sindicato Profesional de Empleados del Ferrocarril de Potrerillos, el 23 de junio de 1940. Sindicato Industrial Obreros de Chile Exploration Company, Sección Antofagasta, fundado el 8 de agosto de 1941. Sindicato Industrial de Obreros de Chile Exploration Company, Chuquicamata, fundado el 22 de agosto de 1957. Galaz-Mandakovic, Damir. 2017. Inclusions, transformations et asymétries du capitalisme minier sur la cote d'Atacama, p. 294.

126 Zapata, Francisco. 1975. "Qué es Chuquicamata”. En Los Mineros De Chuquicamata: ¿productores o proletarios?, México, D. F.: Colegio de México, p. 21.

127 Klubock, Thomas. 2001. Nationalism, race, and the politics of imperialism: Workers and North American capital in the Chilean copper industry. In Reclaiming the political in Latin American history: Essays from the North, ed. G. Joseph, 231-267. Durham, NC: Duke University Press, p. 241.
} 
fronteras a partir de la década de 1920, situación que fortalece los controles sanitarios y de contrabando, así como el aumento de puestos policiales y exigencias de control aduanero ${ }^{128}$.

Fue en ese contexto, primero de cierta hostilidad y precariedad laboral de los bolivianos más las actividades reivindicativas de los obreros chilenos cuando surgió el Centro Boliviano de Socorros Mutuos de Chuquicamata en enero de 1923. Organización social que buscaba "congregar en su seno a todo el elemento boliviano sin distinción de clases sociales, religiones o políticas, procurando por todos los medios prácticos, el mejoramiento moral, cultural, físico y económico de sus asociados"129. Para aquellos propósitos, los socios debían tener buena conducta y un certificado de honorabilidad brindado por algún jefe; debían tener más de 15 años de edad y ser menores de 61; igualmente, no tener enfermedad crónica o contagiosa y tener buena reputación. También se promovía no discutir sobre política ni religión, además de promocionar el deporte y combatir los juegos de azar. Un objetivo importante era no pedir socorro "cuando la enfermedad proviene de excesos alcohólicos"130. Pero se prometía la ayuda en caso de accidente y/o enfermedad a través de bonos en dinero, para lo cual cada socio pagaba una renta mensual. También, se indicaba que: "si el socio fue separado de su empleo o trabajo sin causa justificada, podrá hacer las gestiones más eficaces hasta conseguir su rehabilitación" ${ }^{\prime 131}$. Se adicionaba la ayuda en dinero a las familias que tuvieran problemas económicos y que querían volver a Bolivia, también se brindaba ayuda para cubrir los gastos mortuorios de los socios.

Fue entonces, que los bolivianos se articularon como un modo de protección ante una escena de relaciones asimétricas, cruzadas por el nacionalismo y la resistencia de los obreros chilenos. No obstante, al decaer el ingreso de bolivianos, más el regreso de otros a Bolivia a mediados de la década de 1920, la institución se fue disipando (Figura 11).

\footnotetext{
128 González Miranda, Sergio y González Pizarro, Sergio. 2020. “La frontera que se difumina y endurece”, pp. 119145.

${ }^{129}$ Centro Boliviano de Socorros Mutuos de Chuquicamata. 1923. Estatutos y reglamentos del Centro Boliviano de Socorros Mutuos de Chuquicamata. Antofagasta, Imprenta Moderna, p. 3.

130 Ibíd., p. 6.

131 Ibíd., p. 7.
} 
Figura 11

Ficha laboral de obrero boliviano en Chuquicamata

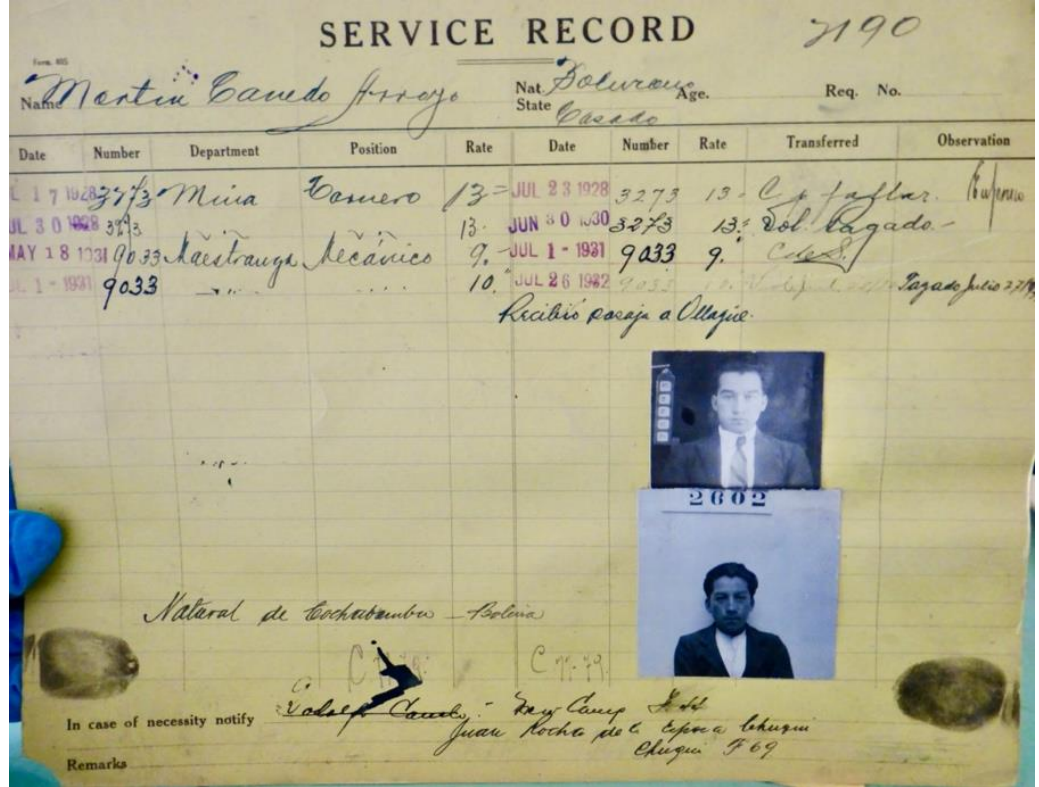

El trabajador que se desenvolvía en el área de tornería y mecánica, era natural de Cochabamba y se señala la fecha en que cesó sus labores en el mineral, indicándose que recibió pasajes hasta Ollagüe, punto fronterizo por donde el ferrocarril (FCAB) ingresaba a Bolivia. Archivo: gentileza de Víctor Tapia Araya.

\section{Conclusiones}

En este trabajo hemos caracterizado la migración boliviana a través de archivos hemerográficos y documentos burocráticos de control migratorio incorporados en los trámites fronterizos Chile-Bolivia. Estos datos permitieron caracterizar la movilidad directa hacia el mineral. Así, pudimos conocer el origen, la edad, los oficios, el género, el estado civil, la alfabetización y los periodos de ingreso de los bolivianos a Chuquicamata en el rango que va desde el año 1881 a 1942.

Cabe mencionar que la presencia boliviana en Chuquicamata expone la magnitud del fenómeno migrante a través de la participación de esta mano de obra en el desarrollo minero a través de oficios específicos, tales como jornaleros, mecánicos, y oficios auxiliares o complementarios como sastres y carpinteros.

La expansión capitalista en el desierto de Atacama durante el siglo XX, atestigua una fluidez de los trasiegos transfronterizos que, quizás, supera la cuantificación de los registros migratorios en una frontera que continuó siendo porosa y de difícil control. La memoria oral nos recuerda que las circulaciones de los pobladores altiplánicos normalmente no quedaban registradas. Por tanto, los archivos documentales, aquellos que son frutos de la pulsión del 
Estado que burocratizó la frontera, iluminan las características de la migración en el marco de la minería ${ }^{132}$.

En síntesis, es posible plantear que la migración boliviana sustentó la expansión del capitalismo minero en Chuquicamata en su primera etapa de industrialización, evidenciándose en sus orígenes lo que identificamos como el carácter subsidiario de esta movilidad laboral, sobre la cual el capital se asentó, y sobre la cual se depositaron los bajos salarios y las precarias condiciones de habitabilidad, con las propias imágenes de desdén y marginalidad hacia aquel colectivo migrante.

Lo anterior debe entenderse en el marco de una relación colonial basada en densos significantes de inferioridad hacia los bolivianos en el periodo que siguió a la conflagración, la cual no solo alteró el territorio minero, sino que alteró la semántica sociológica, siendo el racismo y la adjetivación de "indio" los ejes de la nueva relación social. Los bolivianos que, en los hechos fueron definidos como trabajadores de segunda clase, fueron a la vez fundamentales para la inicial expansión del capitalismo cuprífero en el desierto de Atacama, el cual se consolidó desde la década de 1920.

\section{Referencias citadas}

\section{Entrevistas}

Carlos Puebla, residente en Antofagasta, yerno de Delfín Huanca, entrevista realizada el 8 de enero de 2014, Antofagasta.

\section{Bibliografía}

Álvarez, Alejandro. 1999. Resumen de la historia de Calama, Calama, Ediciones Odisea.

Alvear, Jorge. 1975. Chile, nuestro cobre. Chuquicamata, El Salvador, Potrerillos, El Teniente, ENAMI, Mantos Blancos y Andina, Santiago, Editorial Lastra.

Arce, Isaac. 1997 [1930]. Narraciones históricas de Antofagasta, Antofagasta, Imprenta Moderna.

Centro Boliviano de Socorros Mutuos de Chuquicamata. 1923. Estatutos y reglamentos del Centro Boliviano de Socorros Mutuos de Chuquicamata. Antofagasta, Imprenta Moderna.

Chile Copper Company. 1920. First annual report of the Chile Copper Company, New York.

Collao, Juan. 2001. Historia de Tocopilla, Tocopilla, Editorial Corporación Juan Collao Cerda.

Comisión Central del Censo. 1908. Censo de la República de Chile levantado el 28 de noviembre de 1907, Santiago, Imprenta y Litografía Universo.

Dirección General de Estadísticas. 1925. IX Censo de Población de la República de Chile levantado el 15 de diciembre de 1920, Santiago, Sociedad Imprenta y Litografía Universo.

\footnotetext{
132 Galaz-Mandakovic, Damir; Rivera, Francisco. 2020. Bolivian migration and ethnic subsidiarity in Chilean sulphur and borax high-altitude mining (1888-1946). History and Anthropology, United Kingdom, En prensa, p.10.
} 
Dirección General de Estadísticas. 1931. Resultados del X Censo de Población efectuado el 27 de noviembre de 1930 y estadísticas comparativas con censos anteriores, Santiago, Imprenta Universo.

Figueroa, Marcial. 1928. Chuquicamata: la tumba del chileno, Antofagasta, Imprenta Castellana.

Galaz-Mandakovic, Damir. 2016. "Industrialización minera, urbanización e innovación en las relaciones sociales en el sudoeste del altiplano boliviano: el caso de la Compañía Huanchaca de Bolivia (18341930)", en Estudios Atacameños, № 52, San Pedro de Atacama, pp. 153-175.

Galaz-Mandakovic, Damir. 2017. "Turbinas y electricidad para la mina, lámparas a parafina para la población: crónica de una asimetría del capitalismo minero en Tocopilla (1914-1942)", en Estudios Atacameños, № 54, San Pedro de Atacama, pp. 179-200.

Galaz-Mandakovic, Damir. 2017. Inclusions, transformations et asymétries du capitalisme minier sur la cote d'Atacama: les dérives de la production thermoélectrique a Tocopilla (Chili) 1914-2015, Tesis para optar al grado de doctor en Antropología en Instituto de Arqueología y Antropología, Universidad Católica del Norte, San Pedro de Atacama, y al grado de Doctor en Historia en Université Rennes 2, Rennes, Francia.

Galaz-Mandakovic, Damir. 2020. "The Guggenheim process. Innovaciones y contrapuntos de un sistema técnico y de transporte en la industria del salitre en el Departamento de Tocopilla (Chile, 1926-1949)", en Revista de historia (Concepción), Vol. 2, № 27, Concepción, pp. 175-209.

Galaz-Mandakovic, Damir, Rivera, Francisco. 2020. "Bolivian migration and ethnic subsidiarity in Chilean sulphur and borax high-altitude mining (1888-1946)", en History and Anthropology, United Kingdom doi: https://doi.org/10.1080/02757206.2020.1862106.

Garcés, Alejandro, Moraga, Jorge, Maureira, Mauricio y Saavedra, Adrián. 2019. “Desbordando la Puna de Atacama. Movilidad, economías y etnicidad (1950 al presente)", en Cahiers des Amériques Latines, № 92, París, pp. 49-69.

González Miranda, Sergio y González Pizarro, Sergio. 2020. "La frontera que se difumina y endurece. El espacio de influencia del salitre y los flujos transfronterizos Chile- Bolivia (1880-1930)", en Revista Ciencia y Cultura, Vol. 24, № 44, La Paz, pp. 119-145.

González, José Antonio. 2010. "La industria minera de Antofagasta y la inmigración boliviana durante el ciclo salitrero. Notas para su estudio", en Si Somos americanos: Revista de Estudios transfronterizos, Vol. X, № 2, Iquique, pp. 97-127.

Gutiérrez, Eulogio y Marcial Figueroa. 1920. Chuquicamata: Su grandeza y sus dolores, Santiago, Imprenta Cervantes.

Henríques, Rosario. 2015. Análisis de los niveles de vida y desigualdad en la ciudad de Cochabamba durante el primer siglo republicano, 1825-1925, Universidad Nacional de Educación a Distancia (UNED), Facultad de Ciencias Económicas y Empresariales, Departamento de Economía Aplicada e Historia Económica, Madrid, Tesis para optar al grado de Doctora en Economía.

Illanes, Guillermo. 1915. Mineral de Chuquicamata de la Chile Exploration Company inaugurado el 18 de mayo de 1915. Informe elevado al Supremo Gobierno, Santiago, Imprenta Universitaria.

Joyce, Lilian Elwyn. 1922. Chile today and tomorrow, New York, The Macmillan Company. 
Klubock, Thomas. 2001. "Nationalism, race, and the politics of imperialism: Workers and North American capital in the Chilean copper industry", en Joseph, Gilbert (ed.), Reclaiming the political in Latin American history: Essays from the North, pp. 231-267, Durham, NC: Duke University Press.

Latcham, Ricardo. 1926. Chuquicamata. Estado yankee (visión de la montaña roja), Santiago, Editorial Nascimento.

Lefebvre, Henri. 2013. La producción del espacio, Madrid, Capitán Swing Libros.

Macchiavello, Santiago. 1923. El problema de la industria del cobre en Chile y sus proyecciones económicas y sociales, Santiago de Chile, Imprenta Fiscal de la Penitenciaría.

Martínez, Gerardo. 1993. Orígenes y desarrollo de Chuquicamata bajo la Chile Exploration Company, Santiago, Ediciones Revista Universitaria.

Mesa Gisbert, Carlos, Mesa, Carlos y Gisbert, Teresa. 2007. Historia de Bolivia, La Paz, Editorial Gisbert.

Morel, Enrique. 1990. "The Chuquicamata Complex", en Kennedy, Bruce (ed.). Surface mining, Littleton, Colorado, Society for Mining, Metallurgy and Exploration, Inc. (U.S.), pp. 1140-1150.

O'Brien, Thomas. 1989. "Rich beyond the dreams of avarice: The Guggenheim in Chile", en Business History Review, № 63, Cambridge, pp. 122-159.

O'Connor, Harvey. 1937. The Guggenheims. The making of an american dynasty, New York, Covici, Friede Publishers.

Oficina Central de Estadística en Santiago. 1889. Sesto Censo Jeneral de la población de Chile levantado el 26 de noviembre de 1885 y compilado por la Oficina Central de Estadística en Santiago, Valparaíso, Imprenta de La Patria.

Oficina Central de Estadística. 1900. Sétimo Censo jeneral de la población de Chile levantado el 28 de noviembre de 1895, Valparaíso, Imprenta del Universo de Guillermo Helfman.

Oficina Central de Estadística. 1900. Sétimo Censo jeneral de la población de Chile levantado el 28 de noviembre de 1895, Valparaíso, Imprenta del Universo de Guillermo Helfman.

Orellana, Luis. 2004. "La lucha de los mineros contra las leyes: Chuquicamata (1900-1915)", en Historia, Vol. 37, № 1, Santiago, pp. 169-206.

Pumarino, Héctor. 1978. El Loa, ayer y hoy, Santiago, Ediciones Universitarias.

Revista Ingeniería Internacional. 1922. “El mineral de Chuquicamata”, Tomo 7, № 5, Nueva York, pp. 295 300.

Rodríguez, Gustavo. 1990. “Estado nacional, mercado interior y élites regionales: los casos de Cochabamba y Santa Cruz en Bolivia, (1880-1930)", en Andes, № 2-3, Salta, pp. 11-32.

Rodríguez, Gustavo. 2014. Capitalismo, modernización y resistencia popular 1825-1952, La Paz, Bolivia, Vicepresidencia del Estado de Bolivia-Centro de Investigaciones Sociales.

Semper, E. y Michels, Wilhelm. 1908. La industria del salitre en Chile, Santiago, Imprenta Barcelona.

Tapia, Gustavo. 2001. Chuquicamata, historia con nostalgia. Reportaje de investigación, Antofagasta, Ediciones Parina. 
The Anaconda Company. 1970. Chuquicamata: producer of copper in the Atacama Desert of Northen Chile, New York, Chile Exploration Company, subsidiary of The Anaconda Company.

The Burrage House. 2000. Study report, landmarks commission, Boston, Environment Department.

Valdés, Samuel y Latrille, Francisco. 1886. Informe sobre el estudio minero i agrícola de la rejión comprendida entre el paralelo 23 i la laguna de Ascotán presentado al ministerio del Interior, Santiago, Imprenta Nacional.

Vergara, Alejandro. 1992. Principios y sistema del derecho minero: estudio histórico-dogmático, Santiago, Editorial Jurídica de Chile.

Vilches, Viviana. 2018. Chuquicamata. Evolución de la vivienda en el Campamento Nuevo, Santiago, Andros Impresores.

Zapata, Francisco. 1975. "Qué es Chuquicamata”, en Zapata, Francisco, Los Mineros De Chuquicamata: ¿productores o proletarios?, México, D. F.: Colegio de México, pp. 18-30. 